\title{
A circulação do material probatório do procedimento e do processo penal ao processo tributário e a autonomia decisória do juiz*
}

\author{
The circulation of probative material of criminal procedure and process to the tax process \\ and the judge's decision-making autonomy
}

Alberto Comelli**

\section{REFERÊNCIA}

COMELLI, Alberto. A circulação do material probatório do procedimento e do processo penal ao processo tributário e a autonomia decisória do juiz. Revista da Faculdade de Direito da UFRGS, Porto Alegre, n. 43, p. 36-72, ago. 2020. DOI: https://doi.org/10.22456/0104-6594.105983.

\begin{abstract}
RESUMO
Examina-se a evolução problemática do modelo de conexão entre a investigação preliminar e o processo penal, de um lado, e a confissão de atos impositivos e do processo tributário de outro, partindo-se da pregiudiziale tributaria para alcançar o assim chamado doppio binario. Aprofunda-se a temática fundamental da circulação do patrimônio probatório, ante a conexão acima mencionada, também à luz das diretrizes da jurisprudência de legitimidade, e não da vis espansiva de translatio actionis (o iurisdictionis), codificada no art. 59 da Lei ${ }^{\circ} 69$, de 2009. Enfim, superado definitivamente o modelo do doppio binario "perfeito", se propõe uma reconstrução alternativa, porém na confirmada ausência de prejudicial-dependência, com ampla autonomia decisória do juiz tributário e do juiz penal, o que não deve ser entendido em sentido unilateral.
\end{abstract}

\section{PALAVRAS-CHAVE}

Autonomia decisória do juiz. Material probatório tributário no processo penal. Doppio binario. Pregiudiziale tributaria.

\begin{abstract}
Examination of the problematic evolution of the connection model between the preliminary investigation and the criminal process, on one hand, and the confession of tax acts and the tax process on the other, starting from the pregiudiziale tributaria to achieve the called doppio binario. The fundamental theme of the circulation of probative patrimony is deepened, in view of the aforementioned connection, also in light of the guidelines of the legitimacy jurisprudence, and not of the vis espansiva of translatio actionis (the iurisdictionis), codified in art. 59 of Law No. 69, 2009. Ultimately, once the "perfect" doppio binario model is definitively overcome, an alternative reconstruction is proposed, with the confirmed absence of harmful-dependence, alongside wide decision-making autonomy for the tax judge and the criminal judge, which should not be understood in a unilateral sense.
\end{abstract}

\section{KEYWORDS}

Judge's decision-making autonomy. Tax law probative material in criminal procedure. Doppio binario. Pregiudiziale tributaria.

\section{SUMÁRIO}

1. A conturbada evolução da pregiudiziale tributaria até a vigência do Novo Código de Processo Penal,

\footnotetext{
* Texto publicado originalmente em italiano: COMELLI, Alberto. La circolazione dei materiali probatori dal procedimento e dal processo penale al processo tributario e l'autonomia decisoria del giudice. Diritto e Pratica Tributaria, v. 9, n. 5, p. 2032-2063, set./out. 2019. Tradução de Aline Burin Cella (professora do Departamento de Ciências Jurídicas da Universidade de Santa Cruz do Sul - UNISC; coordenadora do Projeto de Extensão Fiscal Aprendiz; contato: alinecella@unisc.br). Revisão de Mariana Porto Koch (advogada; doutoranda do Programa de Pós-Graduação em Direito da Universidade Federal do Rio Grande do Sul - PPGDir-UFRGS; contato: mariana@koch.com.br).

** Professor do Dipartimento di Giurisprudenza, Studi Politici e Internazionali na Università degli Studi di Parma, onde leciona as disciplinas de Direito Tributário e de Direito Tributário Internacional. Membro da European Association of Tax Law Professors (EATLP).
} 
amplamente inspirado no princípio da autonomia dos processos e nos julgamentos relacionados. 2. A evolução sucessiva: dos arts. $3^{\circ}, 192, \S 2^{\circ}, 479, \S 1^{\circ}$, e 654 do CPP ao art. 20 do Decreto Legislativo $\mathrm{n}^{\circ} 74$ de 2000 e os princípios gerais na conexão entre o processo penal e o tributário. 3. A circulação do patrimônio probatório do julgamento penal para o julgamento tributário e a orientação in parte qua da jurisprudência de legitimidade. 4. O modelo de conexão entre as investigações preliminares e o processo penal por um lado, e a confecção dos atos impositivos e o processo tributário, por autro, tendencialmente diferente do doppio binario "perfeito", sem dependência prejudicial, com a circulação ampla de patrimônio probatório. 5. Notas sobre a eficácia não vinculante para o juiz penal, no lado probatório das sentenças confeccionadas pelas comissões fiscais e sobre a não suspensão do processo tributário, de acordo com o art. 39, § $1^{\circ}$-bis do d. Lgs. $n^{\circ}$ 546, de 1992. 6. A plena compatibilidade do modelo de adaptação proposto em relação à vis expansiva da translatio actionis (ou iurisdictionis) codificada no art. 59 da Lei $n^{0}$ 69, de 2009. 7. A desnecessária suspensão do processo penal (nem mesmo de iure condendo) no aguardo da determinação do imposto devido pelo juiz tributário, com sentença transitada em julgado. 8. Considerações finais: o abandono do doppio binario, a ampla circulação de material probatório e a autonomia decisória do juiz. Referências. Dados da publicação.

1 A CONTURBAdA EVOLUÇÃO DA PREGIUdizIALE TRIBUTARIA ATÉ A VIGÊNCIA DO NOVO CÓDIGO DE PROCESSO PENAL, AMPLAMENTE INSPIRADO NO PRINCÍPIO DA AUTONOMIA DOS PROCESSOS E NOS JULGAMENTOS RELACIONADOS

A questão da conexão entre o processo penal e o processo tributário, nos casos em que os dois processos se referem aos mesmos fatos materiais e fiscalmente relevantes, é, sem dúvida, complexa e muito atual ${ }^{1}$ : deve-se estabelecer qual é o modelo de conexão, com base na sua evolução ex positivo iure e se isso garante que as controvérsias sejam resolvidas de maneira homogênea. Este ensaio, no entanto, levará em consideração apenas o imposto de renda e o IVA, e permanecerá em segundo plano a mesma problemática ajustada sobre impostos especiais de consumo ${ }^{2}$, ou sobre outros tributos.

Para enquadrar sistematicamente a rica rede de relações entre os processos penal e tributário $^{3}$, é necessário começar com o reconhecimento dos dados normativos no aspecto

1 Salienta AMATUCCI, F. Doppio binario e "connessione sufficiente" tra procedimento tributario e penale. Rivista trimestrale di diritto tributario, a. 2017, n. 2, p. 271 e ss., 2017, p. 272 e 273, que o doppio binario e a autonomia entre os procedimentos penal e tributário subjacente está em crise há algum tempo, devido às "[...] interrelações contínuas entre as duas esferas e atividades de avaliação que não são mais tão separadas e distantes". Segundo o autor, as novidades legislativas e as orientações da jurisprudência nacional e européia lançaram as bases para "[...] uma aproximação entre as diversas etapas preliminares, respeitando as diferenças que as caracterizam". Como consequência, "[...] os dois assuntos começaram a se cruzar mais e mais vezes, pois há várias contaminações entre os diferentes modelos de apuração". Acrescenta GUIDI, D. I rapporti tra processo penale e processo tributario ad oltre dieci anni di distanza dal D.Lgs. n. 74 del 2000. Dir. pen. e processo, p. 1384 e ss., 2012, que a relação entre os processos penal e tributário, em nosso ordenamento, "[...] sempre foi caracterizada por um alto coeficiente de problemas e mútua 'desconfiança'".

2 Para a qual se faz referência à DONELLI, F. Le fattispecie penali in materia di accise. In: CADOPPI A. et al. (coords.). Diritto penale dell'economia. t. 1. 2. ed. Milano: Utet Giuridica, 2019 (no prelo); e BIANCHI, L. Le sanzioni tributarie in materia di accise. In: CADOPPI, op. cit.

3 Neste ensaio a disciplina dos custos do crime não será examinada [para esse problema, por favor, consulte CARINCI, A. La nuova disciplina dei costi da reato: dal superamento del doppio binario alla dipendenza rovesciata (con diversi dubbi e numerose incongruenze). Rassegna tributaria, p. 1459 e ss, 2012], a duplicação 
temporal, à luz da qual emerge a mudança radical de perspectiva que ocorreu com a passagem da pregiudiziale tributaria $a^{a}$ para o chamado doppio binario. Com referência aos impostos diretos (e, sucessivamente, também ao IVA) foi confirmada a abordagem segundo a qual a tarefa de resolver questões penais ou tributárias, com relação aos mesmos fatos materiais, não deve ser atribuída ao mesmo juiz.

Em consonância com o art. 21, § $3^{\circ}$, da Lei ${ }^{\circ}$ 4, de 7 de janeiro de 1929, nos crimes individuais “[...] da lei sobre tributos diretos, a ação penal transcorre depois que a apuração do imposto e da relativa sobrecarga tributária se tornou definitiva, de acordo com as disposições que regulam a matéria”. Nesse sistema, a uniformidade dos julgados era salvaguardada mediante a subordinação da ação penal a uma decisão preliminar do processo tributário ${ }^{4}$. Em outras palavras, o exercício da ação penal só poderia ocorrer após a definição preliminar do processo tributário ${ }^{5}$, com suspensão do prazo de prescrição do crime tributário, enquanto se aguardava a apuração e o processo tributário.

dos prazos dentro dos quais deve ser notificado, sob pena de decadência, o ato impositivo, na presença de violações que envolvam a obrigação de denúncia criminal [na doutrina, sobre duplicação dos prazos, consulte, CORSO, P. Raddoppio dei termini di accertamento tra Legge delega e Suprema Corte. Corriere tributario, $\mathrm{p}$. 2235 e ss., 2015; FRANSONI, G. Osservazioni controcorrente sul doppio termine dell'accertamento. Rassegna tributaria, p. 311 e ss., 2012;MARELLO, E. Il raddoppio dei termini per l'accertamento al vaglio della Corte Costituzionale. Rassegna tributaria, p. 1296 e ss., 2011; Id. Raddoppio dei termini per l'accertamento e crisi del "doppio binario". Rivista di diritto tributario, v. 20, n. 3, p. 85 e ss., 2010; RANDAZZO, F. Per il raddoppio dei termini dell'accertamento tributario necessaria la denuncia di reato. Corriere tributario, p. 1533 e ss., 2015; STEVANATO, D. Il raddoppio dei termini per l'accertamento nella sentenza della Corte costituzionale n. 247/2011: una pronuncia dagli effetti (involontariamente) criminogeni? Dialoghi tributari, p. 474 e ss., 2011], assim como o problema de não bis in idem em face de sanções tributárias administrativas impostas ao mesmo destinatário da sanção tributária penal, à luz da jurisprudência da Corte Europeia de Direitos Humanos e da Corte di cassazioni [sobre essa questão, inter alios, cfr. AMATUCCI, F. Le sanzioni amministrative tra principio di proporzionalità e ne bis in idem. In: COMELLI, A. (coord.). Nuove problematiche e prospettive di evoluzione del sistema dell'iva. Atti del VII convegno annuale 23 marzo 2017 (23 mar. 2017). Canterano (RM): Aracne, 2018. p. 57 e ss.; Id. Doppio binario e "connessione sufficiente" tra procedimento tributario e penale. Rivista trimestrale di diritto tributario, a. 2017, n. 2, p. 271 e ss., 2017; GIOVANNINI, A. La Corte EDU ribadisce il divieto di doppia sanzione e la Cassazione rinvia alla Consulta. Corriere tributario, p. 905 e ss., 2015; RUSSO, P. Il principio di specialità ed il divieto del ne bis in idem alla luce del diritto comunitario. Rivista di diritto tributario, v. 26, n. 1, p. 23 e ss., 2016; SCHIAVOLIN, R. Alcune considerazioni sul contrasto tra CEDU e disciplina italiana dei rapporti tra procedure sanzionatorie amministrative e penali. Rivista di diritto tributario, v. 27, n. 1, p. 385 e ss., 2017]. Com referência aos perfis comparativos, cfr. o ensaio de PIETRO, A. di. Diritto penale tributario: profili comparati. Rassegna tributaria, p. 333 e ss., 2015.

aaaaa N. T: A pregiudiziale tributaria se tratava de um instituto previsto na Lei italiana $\mathrm{n}^{\circ} 4$ de 1929 com base no qual a ação penal para as infrações previstas em matéria de impostos diretos, cuja verificação exigia uma quantificação da evasão por meio da aplicação de normas tributárias, não podia ter continuidade enquanto não fosse definido o processo tributário. A pregiudiziale tributaria se traduzia em uma possibilidade concreta de que fosse a Administração quem decidiria sobre a existência da infração.

4 Nesse sentido: LA ROSA, S. Principi di diritto tributario. Torino: Giappichelli, 2016.

5 Portanto, o juiz penal foi impedido de realizar apurações que poderiam ser consideradas não relacionadas à sua área jurídica, em um sistema no qual os delitos tributários eram estruturados principalmente como crimes de dano e o evento consistia em sonegação fiscal, cuja apuração era particularmente complexa e, portanto, dedicada exclusivamente às repartições fiscais: nesse sentido, cfr. STAGNO, M. Art. 20 d.lg. n. 158/2015. In: NOCERINO, C.; PUTINATI, S. (coords.). La riforma dei reati tributari. Torino: Giappichelli, 2015. p. 390. 
Uma vez definido esse último, a causa da não admissibilidade cessava e o juiz penal ficava vinculado aos resultados da apuração realizada pela administração tributária, em termos da determinação do imposto evadido, e essa vinculação se estendia até a hipótese de instrumentação indutiva, pela própria administração tributária, mesmo que não fosse admitida em processo penal ${ }^{6}$. Esse sistema, no entanto, estava claramente em contraste com as necessidades imediatas de eficácia e equidade que deveriam caracterizar a repressão de comportamentos penalmente relevantes, no âmbito tributário. A partir de um perfil diferente, mas simultâneo, a eficácia vinculativa para o juiz penal de apuração fiscal, realizada em sede administrativa, deveria ser considerada incompatível com o princípio da livre convicção, que deve ser entendido em um sentido ainda mais rigoroso nos processos penais.

Essa premissa refletiu-se na declaração de inconstitucionalidade do art. $21, \S 2^{\circ}$ (juntamente com o art. 60), da Lei $\mathrm{n}^{\mathrm{o}}$ 4, de 1929, pronunciado pela Consulta na sentença n. 88 de $1982^{7}$, na parte onde se verifica “[...] que a apuração do imposto relacionado, que se tornou definitivo administrativamente, ocorra nos processos penais pelo conhecimento dos crimes previstos nas leis tributárias, relativas aos impostos diretos”. Em particular, segundo a Corte, o art. 24 da Constituição "[...] é ferido na medida em que a apuração administrativa realizada no processo penal impede o exercício do inviolável direito à defesa", enquanto o art. $3^{\circ}$ da Constituição é violado “[...] porque a preclusão para o juiz penal, que advém da apuração administrativa em matéria tributária, diferencia irracionalmente a condição dos acusados, dependendo se a imputação é consequente ou não, de uma apuração tributária administrativa e, no contexto das apurações tributárias administrativas, está relacionada a impostos diretos ou indiretos".

A necessidade de estabelecer conexão entre a apuração e o processo tributário, de um lado, e o processo penal, de outro, sob uma perspectiva diferente, também surge claramente à luz da sentença de Consulta $\mathrm{n}^{\mathrm{o}} 247$ de $1983^{\circ}$. Foram aprofundados os argumentos contidos no julgamento anterior - sentença $\mathrm{n}^{\circ} 88$ de 1982, afirmando que "[...] deve ser considerado em contraste com o art. 24 da Constituição a previsão cuja apuração se tornou definitiva em decorrência da decisão de uma comissão tributária, que vincula aos mesmos efeitos penais aqueles que permaneceram estranhos a esse julgamento, porque não intervieram ou

6 Assim LA ROSA, op. cit., p. 424.

7 Sentença publicada em 27 abr. 1982, nos termos dos parâmetros mencionados nos artigos 3, 24 e 101, § 2, da Constituição.

8 Sentença publicada em 15 jul. 1983. 
participaram dele" ". Alguns meses após a publicação da sentença $\mathrm{n}^{\circ} 88$ de 1982, ocorreu o Decreto Legislativo $n^{\circ} 429$, de 10 de julho de $1982^{10}$, que revogou o art. 21 , § $3^{\circ}$, da Lei $n^{\circ} 4$, de $1929^{11}$ e introduziu uma disposição destinada a disciplinar a relação entre as duas possíveis iniciativas processuais em termos de doppio binario, ou seja, "tendência de autonomia mútua" ${ }^{2}$. Em virtude do art. 12, $\S 1^{\circ}$ desse Decreto Legislativo, "[...] embora o disposto no art. $3^{\circ}$ do CPP, o processo tributário não pode ser suspenso; no entanto, a sentença irrevogável de condenação ou absolvição, pronunciada após a sentença relativa a crimes previstos em matéria de imposto de renda e de imposto sobre o valor agregado, faz coisa julgada no processo tributário, em relação aos fatos materiais que foram objeto do julgamento penal"13.

O parágrafo citado continha duas disposições diferentes, sendo que a primeira afirmava a não suspensão do processo tributário, embora o julgamento penal estivesse pendente. A segunda, por outro lado, respeitou os efeitos produzidos pela condenação final ou sentença de absolvição, pronunciada após processos penais fiscais, em matéria de imposto de renda e ou IVA.

Esse julgamento adquiriu a autoridade da coisa julgada no processo tributário, exclusivamente do ponto de vista dos fatos materiais relevantes que tenham sido "objeto de julgamento penal" ${ }^{14}$. O citado art. $12, \S 1^{\circ}$, exatamente como destacado, havia levantado numerosas e delicadas questões, dentre as quais destaca-se a compatibilidade com o Novo Código do Processo Penal, aprovado pelo Decreto Presidencial n 447 de 1988, amplamente inspirado no princípio da autonomia dos processos e julgamentos relacionados ${ }^{15}$.

\footnotetext{
9 A disposição declarada constitucionalmente ilegítima era o art. 56, último parágrafo, do D.P.R. n. 600, de 29 set. 1973.

10 Convertido com modificações da Lei no 516, de 7 ago. 1982.

11 Cfr. o art. 13 do D. L. no 429 de 1982.

12 É assim que se expressa, com muita precisão, LA ROSA, S. Principi di diritto tributario. Torino: Giappichelli, 2016. p. 425. Prefere afirmar a "total autonomia entre julgamentos" (COMOGLIO, L. P. Prove penali, "giusto processo" e poteri di acquisizione del giudice tributario. Diritto e pratica tributaria, v. 71, n. 4, p. 943-971, 2000. p. 965), segundo o qual o juiz tributário tem o poder de fazer uso de provas derivadas de fontes atípicas, e o uso de provas formadas ou assumidas e adquiridas em outros julgamentos, por exemplo, no curso de um processo penal.

13 Sobre a relação entre o julgamento penal e o art. 12 do Decreto Legislativo ${ }^{\circ} 429$, de 1982 , à luz do sistema de relações entre o processo penal e o processo tributário, cfr. SCHIAVOLIN, R. L'utilizzazione fiscale delle risultanze penali. Milano: Giuffrè, 1994. p. 555 e ss.

14 Cfr. Corte Constitucional, 29 out. 1987, $\mathrm{n}^{\circ}$ 349, a qual declarou improcedente a questão da legitimidade constitucional do art. $12, \S 1^{\circ}$, do Decreto Legislativo $\mathrm{n}^{\mathrm{o}} 429$ de 1982, convertido com modificações pela Lei $\mathrm{n}^{\circ}$ 516 de 1982, levantada em referência aos artigos 2, 3, 24, 25 e 53 da Constituição.

15 No mesmo sentido, cfr. TABET, G. Collegamento tra fattispecie tributaria e fattispecie penale: riflessioni di diritto processuale. Rassegna tributaria, p. 303 e ss., 2015.
} 
2 A EVOLUÇÃO SUCESSIVA: DOS ARTS. $3^{\circ}$; 192, § $2^{\circ} ; 479, \S 1^{\circ}$; E 654 DO CPP AO ART. 20 DO DECRETO LEGISLATIVO No 74 DE 2000 E OS PRINCÍPIOS GERAIS NA CONEX̃̃O ENTRE O PROCESSO PENAL E O TRIBUTÁRIO

Com entrada em vigor do Novo Código de Processo Penal italiano, as relações entre os dois diferentes ritos processuais em exame evoluíram ainda mais, com particular referência aos arts. $3^{\circ}, 479, \S 1^{\circ}$, e 654 do CPP. Esse último apresenta alguns problemas quanto à interpretação e requer reflexão cuidadosa dos efeitos da sentença penal definitiva, seja essa de condenação ou absolvição, em comparação a outros julgamentos civis ou administrativos. $\mathrm{O}$ dispositivo, aparentemente aplicável também ao processo tributário, sujeita a eficácia vinculante da sentença penal a múltiplos requisitos. In primis, nos termos do art. 654 do CPP, a sentença penal definitiva se aplica ao acusado e à parte civil, que foi constituída ou interveio no processo penal.

Consequentemente, só pode produzir esse efeito vinculativo no processo tributário se a Administração Tributária foi constituída ou interveio no processo penal, como parte civil. E isso nem sempre acontece, pois é problemático configurar um dano indenizável em favor de um sujeito que já possui poderes de autoridade significativos, o que permite recuperar o imposto evadido e impor as sanções administrativas relacionadas, embora seja abstratamente concebível o dano (considerado de natureza moral) essencialmente constituído pelo "prejuízo do interesse público subjacente às regras tributárias"16.

Um segundo limite para a eficácia vinculante da sentença penal irrevogável é constituído em razão de ter sido "pronunciada após uma audiência", e essa frase exclui alguns tipos de decisões daquelas com probabilidade de gerar restrições ao juiz tributário. Mas o limite mais significativo à eficácia vinculante do julgamento penal é a ausência, na "lei civil", de "limitações à prova da posição subjetiva em disputa".

No processo tributário, "o juramento e a prova testemunhal não são admitidos" (típicos), em virtude do art. $7^{\circ}, \S 4^{\circ}$, do Decreto Legislativo $n^{\circ} 546$, de 1992. Assim como essa disposição, no processo tributário estão previstas limitações significativas no plano probatório, que dificultam a eficácia vinculativa da sentença penal, ainda que, hipoteticamente, os outros dois requisitos estejam satisfeitos.

16 O termo é de LA ROSA, S. Principi di diritto tributario. Torino: Giappichelli, 2016. p. 425. 
Além disso, na execução dos poderes de investigação e dos procedimentos de apuração tributária, presunções sem os requisitos de gravidade, precisão e concordância ${ }^{17}$ podem ser utilizadas pela administração fiscal, os quais, entretanto, devem existir simultaneamente, para fins de valoração da prova, no lado processual penal ${ }^{18}$, em virtude do art. 192, $\S 2^{\circ}$, do CPP, onde, na ausência deles, seriam meros indícios ${ }^{19}$ dos quais o juiz não pode inferir a existência de um fato $^{20}$.

Tudo o que resta é concluir no sentido de que, nesse ponto, não pode ser reconhecida nenhuma autoridade automática da coisa julgada na sentença penal definitiva, no julgamento tributário $^{21}$, ainda que os fatos apurados na seara penal sejam os mesmos em relação àqueles que a administração tributária considerou no exercício dos poderes administrativos perante o contribuinte sob investigação ${ }^{22}$.

17 Pense no art. $39, \S 2^{\circ}$, do Decreto Presidencial $n^{\circ}$ 600, de 29 set. 1973, com referência aos rendimentos apurados com base nos registros contábeis.

18 Por força do Decreto Legislativo $\mathrm{n}^{\circ} 429$ de 1982, convertido com alterações pela Lei $\mathrm{n}^{\circ} 516$ de 1982. GRANELLI, A. E. Presunzioni tributarie e processo penale. Diritto e pratica tributaria, a. 1985, n. 1, p. 34 e ss., 1985 , p. 34 e ss., e especialmente p. 53, afirma que não há nenhum valor condicionante, na formação do convencimento do juiz penal, a presunções sobre os quais se baseiam as apurações tributárias, sejam legais ou simples, absolutas ou relativas.

19 Destaca Cass. pen., 17 fev. 2015, $\mathrm{n}^{\mathrm{o}}$ 6823, em julgamento sobre a responsabilidade por crime de omissão de declaração anual para fins de IVA, em que a avaliação presuntiva, embora admitida na área tributária, "[...] não pode ingressar na seara penal, pois o juiz deve verificar a existência da violação por meio de investigações específicas que possam esclarecer a validade ou não da tese acusatória". E acrescenta a Corte que "é responsabilidade do juiz penal realizar a apuração e determinação do valor do imposto evadido, através de uma verificação que pode se sobrepor ou mesmo entrar em contradição com aquela eventualmente realizada perante o juiz tributário". Além disso, o juiz penal não pode limitar-se a aplicar as presunções legais, ainda que relativas, ou os critérios de valoração previstos na seara tributária, impondo o ônus da prova ao contribuinte, devendo, ao contrário, "proceder de ofício as apurações do caso, eventualmente recorrendo as presunções de fato". Em relação à subsistência do crime de declaração infiel, segundo Cass. pen., 9 set. 2014, n ${ }^{\circ}$ 37302, para fins de investigação criminal, "dados factuais reais devem prevalecer sobre os critérios de natureza meramente formal que caracterizam o ordenamento tributário". Nesta perspectiva, as presunções legais previstas pela disciplina tributária "não podem constituir por si só fonte de prova da prática do crime, assumindo apenas o valor dos dados factuais, que devem ser avaliados livremente pelo juiz penal juntamente com evidências que garantem a existência da conduta criminosa" (conforme Cass. pen. 18 jan. 2019, no 2342; Cass. pen., 18 fev. 2019, $\mathrm{n}^{\mathrm{o}}$ 7242; Cass. pen. 30 maio 2019, $\mathrm{n}^{\circ}$ 24152, segundo o qual as presunções fiscais representam um “'atalho' probatório a favor da administração pública competente", o que implica a inversão do ônus da prova em desfavor do contribuinte. Na seara penal, permanece esta acepção, não se aplica a presunção legal e vigora o princípio do livre convencimento do juiz, onde não é o acusado que deve comprovar sua inocência e sim o Ministério Público que deve provar a responsabilidade penal do mesmo, sendo inadmissível a inversão do ônus probatório).

20 Afirma Cass. pen., 10 mar. 2014, $\mathrm{n}^{\circ} 11380$, que a apuração do crime não pode se basear exclusivamente nas presunções tributárias, uma vez ser necessário que a promotoria apresente prova tanto dos elementos materiais quanto dos psicológicos. Em sintonia, Cass. pen., 20 fev. 2018, n 8047, destaca "que as presunções tributárias não constituem, por si só, prova da prática de um crime, mas assumindo exclusivamente o valor dos dados factuais livremente passíveis de avaliação pelo juiz, podem ser a base para uma medida cautelar real", quando, no caso examinado pela Corte, envolvesse uma apreensão preventiva destinada ao confisco por equivalente.

21 Também chegaram à mesma conclusão FALSITTA, G. Manuale di diritto tributario. Parte generale. Padova: CEDAM, 2017. p. 534; FRANDAZZO, F. Manuale di diritto tributario. Torino: Giappichelli, 2018. p. 308, que afirma a ineficácia da sentença penal no processo tributário. Veja também VIGONI, D. L'effetto vincolante del giudicato penale in altri settori dell'ordinamento: le coordinate normative. Rivista di diritto processuale, v. 72, n. 4-5, p. 912 e ss., 2017.

22 Cass., sez. VI, 18 jun. 2013, n ${ }^{\circ} 15190$, recorda sua própria orientação segundo a qual, nos termos do art. 654 do CPP, "[...] a eficácia vinculante da sentença penal não opera no processo tributário, pois, de um lado, existem 
O habitat processual permanece totalmente distinto, com referência a esses dois ritos, em relação aos quais se aplicam disposições específicas ${ }^{23}$; os dois processos são celebrados em posição de autonomia mútua ${ }^{24}$ e são colocados, um em relação ao outro, em posição de equilíbrio, na ausência da previsão, de lege lata, de uma decisão preliminar tributária ou penal, como seria abstratamente concebível.

No entanto, essa estrutura não resolve coerentemente o problema de juízes potencialmente divergentes ao final do respectivo iter processual. De fato, verificar um contraste de casos julgados aparenta ser insanável ${ }^{25}$ e representa um limite não pouco significativo em relação à configuração do modelo de ajuste em questão.

Por outro lado, o art. 25 do Decreto Legislativo $n^{\circ}$. 74, de 2000, revogou o art. 12 do Decreto Legislativo $n^{\circ} 429$, de 1982, e revelou uma importante mudança de rumo ${ }^{26}$. O art. 20 do mesmo decreto legislativo afirma que “[...] não se pode suspeitar do procedimento de apuração administrativa e do processo tributário devido aos processos criminais pendentes, com relação aos mesmos fatos, ou fatos cuja apuração ainda dependa de definição" 27 .

limitações quanto às provas e, de outro, podem ser aplicadas presunções inadequadas para embasar uma sentença penal condenatória" (destaca Cass. pen., 6 maio 2014, $\mathrm{n}^{\mathrm{0}} 18715$, que as presunções legais previstas pelas disposições tributárias têm valor meramente circunstancial ou, melhor dizendo, os fatos subjacentes a essas suposições, os quais "[...] devem ser livremente valorados pelo juiz penal juntamente com evidências que garantam a existência da conduta criminosa"; no mesmo sentido, cfr. Cass. pen., 13 fev. 2013, n 7078; Cass. pen., 12 jun. 2019, n 25976). Em sintonia, afirma Cass., sez. trib., 22 jun. 2010, no 14960, que "[...] nenhuma autoridade automática de coisa julgada pode então ser atribuída, em processos tributários separados, ao julgamento penal irrevogável, de condenação ou absolvição, proferida em matéria de crimes tributários, mesmo que os fatos apurados na seara penal sejam os mesmos para os quais a Administração Financeira tenha promovido a autuação contra o contribuinte" (no mesmo sentido, cfr. Cass. sez. VI, 28 jun. 2017, $\mathrm{n}^{\circ}$ 16282; Cass., sez. trib., 14 mar. 2018, n 6295; Cass. sez. VI, 26 fev. 2019, n 5546, que considera essa orientação como consolidada). De acordo com essa premissa, segundo a Corte, o juiz tributário deve exercer seus "[...] poderes autônomos de avaliação da conduta das partes e do material comprobatório adquirido nos documentos" (incluindo depoimentos de testemunhas e perícias realizadas no processo penal), verificando a relevância no caso processual específico que lhe é submetido.

23 Cfr., nesse sentido, NANNUCCI, U. I rapporti tra il procedimento penale e il processo tributario. In: NANNUCCI, U.; D'AVIRRO, A. (coords.). La riforma del diritto penale tributario (D.Lgs. 10 mar. 2000, n. 74). Padova: CEDAM, 2000. p. 360.

24 Segundo MANONI, E. Riflessioni sul rapporto tra sistema penale e sistema tributario. Rassegna tributaria, $\mathrm{p}$. 1034 e ss., 2014, há uma influência indubitável, ou seja, uma indiferença não recíproca entre o procedimento e o processo penal, de um lado, e o procedimento e processo tributário de outro, e se aplicaria in parte qua o art. $4^{\circ}$, do Decreto Legislativo $n^{\circ} 2248$ de 1865 , anexo E, como interpretado pela Corte Constitucional.

25 No mesmo sentido, cfr. CARACCIOLI, I. Salvato a metà dai giudice europei il doppio binario tributariopenale. Corriere tributario, p. 1029 e ss., 2013. p. 1029.

26 A clara mudança de rumo traçada pelo d. LGS. $n^{\circ}$ 74/ 2000 e bem sublinhado por TABET, G. Collegamento tra fattispecie tributaria e fattispecie penale: riflessioni di diritto processuale. Rassegna tributaria, p. 303 e ss., 2015, o qual indica justamente entre as causas, a renúncia à criminalização de violações formais e padrônicas, o abandono da técnica de crimes com consumo preventivo e a concentração das cifras em um número muito limitado de casos, apenas de natureza criminosa e caracterizada por uma ofensiva significativa. Cfr. Também NAPOLEONI, V. I fondamenti del nuovo diritto penale tributario. Milano: Ipsoa, 2000. passim.

27 Afirma RUSSO, F. L'equilibrio storico sistematico tra processo penale e tributario alla luce dei principi CEDU e pronunce della Corte EDU. Diritto e pratica tributaria internazionale, 2017, p. 136, que o art. 20 do d.lgs. n. 74 de 2000 consagrou a "total autonomia" entre os processos criminais e tributário, com o risco concreto de julgamentos conflitantes. Segundo MANCINI, A. Diritto penale tributario. Roma: Laurus Robuffo, 2019. p. 
Essa disposição acentua o quadro das relações entre os processos criminais e fiscais à luz dos princípios gerais relativos à conexão entre o processo penal, de um lado, e o processo civil e administrativo, de outro ${ }^{28}$.

Em particular, o art. 20 do Decreto Legislativo $n^{\circ} 74$ de 2000, em harmonia com o princípio da autonomia dos processos e do repúdio à unidade de jurisdição ${ }^{29}$, esculpe a regra da independência e da não interferência mútua entre o processo tributário e o processo penal $^{30}$, o que parte da doutrina denominou doppio binario "perfeito", aplicável tanto a procedimentos judiciais quanto às sentenças relacionadas ${ }^{31}$. $\mathrm{O}$ art. 20 , em comparação com o anterior art. $12, \S 1^{\circ}$ do Decreto Legislativo $\mathrm{n}^{\circ} 429$, de 1982, confirma a plena autonomia do processo tributário, também estendido ao cumprimento dos poderes administrativos de investigação e à elaboração de documentos tributários (pela administração tributária), o qual não pode ser suspenso em relação ao processo penal, referente aos mesmos fatos tributários relevantes $^{32}$, tanto que a eficácia externa do julgamento penal não foi confirmada (na verdade,

363 e 366 , o art. 20 do d.lgs. n. 74 de 2000 afirma plena autonomia entre os processos criminais e fiscais, enquanto as "possíveis conexões probatórias entre os dois processos" são pacíficos, com referência ao uso, no lado tributário, dos elementos de investigação e/ou evidência adquiridos no curso de investigações criminais, "sem fornecer qualquer limitação à eficácia probatória desses documentos".

28 Afirmam TOPPAN, A.; TOSI, L. Lineamenti di diritto penale dell'impresa. Milano: CEDAM, 2017. p. 268 e 269, que o art. 20 do d.lgs. n. 74 de 2000 estabelece o princípio de autonomia e independência entre julgamentos criminais e tributários, com pelo menos um contraste potencial de julgamentos que decorre da diversidade de ambos os juizes chamados a avaliar os fatos, as regras e regimes probatórios (considere a inadmissibilidade do típico testemunho pericial no processo tributário, nos termos do art. $7, \S 4^{\circ}$, do d. Lgs. ${ }^{\circ} 546$ de 1992).

29 Affirma SATTA, S. Giurisdizione (nozioni generali). In: ENCICLOPEDIA del diritto. v. XIX. Milano: Giuffrè, 1970. p. 218, que a jurisdição é "um momento essencial e jurídico", que "[...] não pode ser entendido, exceto na contemplação integral daquela vida e de suas estruturas profundas" e a essência da jurisdição "[...] é dada pelo vínculo ou pelo relacionamento entre e lei e o julgamento". Destaca ainda na página 224 que a jurisdição "[...] expressa a afirmação do ordenamento no caso concreto, isto é, onde somente lá a afirmação pode ser feita: ela é, portanto, como tal, o único momento essencial da organização da societas, porque sem jurisdição o mesmo sistema seria menor, ou melhor, a natureza jurídica do sistema". Cfr. também CABRAL, A. Per un nuovo concetto di giurisdizione. In: BRIGUGLIO, A. et al (coords.). Scritti in onore di N. Picardi. T. I. Pisa: Pacini, 2016. p. 365 ss.; com referência à jurisdição penal, v. PISANI, M. Giurisdizione penale. In: ENCICLOPEDIA del diritto. v. XIX. Milano: Giuffrè, 1970. p. 381 e ss.

30 STEVANATO, D. Fondamenti di diritto tributario. Firenze: Le Monnier Università, 2019. p. 418, salienta que o art. 20 del d.lgs. $\mathrm{n}^{\circ} 74$ de 2000 , postula o princípio da autonomia e da não ingerência mútua dos dois processos. Em outras palavras, de acordo com o autor, eles permanecem independentes, podem prosseguir em paralelo e terminar com resultados potencialmente diferenciados. Cfr. também Id. Procedimento tributario e nuovi reati: l'accertamento divenuto definitivo vincola il giudice penale? In: LUPI, R. (coord.). Fiscalità d'impresa e reati tributari. Milano: Il Sole 24 Ore, 2000. p. 195, segundo o qual, em virtude do princípio da autonomia e paralelismo tendencial entre o processo criminal e o processo tributário, seguindo também o d. Lgs. $\mathrm{n}^{\circ} 74$ de 2000, “[...] não há espaço para uma transferência automática dos resultados do julgamento criminal no processo tributário".

31 Nesse sentido, v. TABET, G. Collegamento tra fattispecie tributaria e fattispecie penale: riflessioni di diritto processuale. Rassegna tributaria, p. 303 e ss., 2015.

32 Sublinha exatamente PISTOLESI, F. Il principio del doppio binario e l'utilizzabilità delle prove penali nel processo tributario. Fisco e reato. Atti delle "Giornate di Studi", Brescia (24 abr. 2015), Catania (19 jun. 2015) e Bologna (16 out. 2015). Pisa: Pacini, 2016. p. 201, também a relação entre os processos de apuração e o processo tributário, por um lado, e o julgamento criminal por crimes relacionados ao imposto de renda e ao IVA, por outro, "[...] nos últimos tempos, tornou-se cada vez mais importante e renovado o interesse, devido a algumas 
foi suprimida). Como consequência, essa eficácia não é mais disciplinada por uma regra especial, e sim, aplicam-se os princípios e regras contidos no Novo Código de Processo Penal e, em particular, é regulado pelo art. 654, ut supra analisado.

É uma questão de saber se é correto enquadrar o módulo de conexão em questão em termos de doppio binario "perfeito" ou, ao contrário, se essa reconstrução deve ser abandonada $^{33}$, o que está definitivamente superado, da mesma maneira que a experiência jurisprudencial de legitimidade.

\section{A CIRCULAÇÃo do PATRIMÔNIO PROBATÓRIO dO JULGAMENTO PENAL PARA O JULGAMENTO TRIBUTÁRIO E A ORIENTAÇÃO IN PARTE QUA DA JURISPRUDÊNCIA DE LEGITIMIDADE}

De acordo com o art. 654 do Código Penal italiano, já foi apontado que o julgamento penal não vincula o juiz tributário, no sentido de que a sentença criminal irrevogável de condenação ou absolvição, pronunciada em consideração aos mesmos fatos relevantes apurados, não produz automaticamente nenhum efeito vinculativo com relação ao julgamento tributário ainda pendente. Essa suposição, no entanto, não pode ser interpretada de maneira formalista, no sentido de que o julgamento penal e o tamquam non esset para o juiz tributário, antes do qual o julgamento penal irrevogável foi produzido ritualmente ${ }^{34}$.

\footnotetext{
inovações legislativas". Veja ainda IANNACCONE, G. Diritto tributario e processo penale. In: GLENDI, C. et al (coords.). Per un nuovo ordinamento tributario. Atti del convegno di Genova del 14-15 out. 2016, in occasione dei Novant'anni di Diritto e pratica tributaria. t. 2. Milano: CEDAM, 2019. p. 1445-1457.

33 FPISTOLESI, F. Crisi e prospettive del principio del "doppio binario" nei rapporti fra processo e procedimento tributario e giudizio penale. Rivista di diritto tributario, v. 24, n. 1, p. 38 e ss., 2014, fala de "degradação do princípio" do doppio binario, bem como de sua crise (no titulo do ensaio e pag. 48). Segundo MARELLO, E. Evanescenza del principio di specialità e dissoluzione del doppio binario: le ragioni per una riforma del sistema punitivo penale tributario. Rivista di diritto tributario, v. 23, n. 3, p. 270 e ss., 2013, p. 270 e 272, a repressão criminal é caracterizada como uma razão extrema, ou seja, "como o sinal máximo de reprovação legal (e como a ferramenta de prevenção mais relevante)". No entanto, ressalta o autor, os dois sistemas punitivos, o administrativo e o criminal, estão "[...] longe de qualquer coordenação e entraram em colisão total, com efeitos distorcidos e não toleráveis". O estado de crise do doppio binario e os numerosos perfis de críticas decorrentes do desalinhamento em relação à abordagem original, com base em uma autonomia teórica entre processos criminais e tributários é sublinhada por TRAVERSI, A. La crisi del "doppio binario" tra contenzioso fiscale e processo penale. Fisco, p. 3800 e ss., 2011. SIENA, M. di. Rapporti tra processo tributario e procedimento penale. In: LIBRO dell'anno di diritto. Roma: Ist. Enciclopedia Italiana, 2013. p. 447 e ss., afirma a existência de uma profunda crise na dupla, que decorre da crise do princípio da separação estrita entre processo penal e o processo tributário.

34 Afirma MITA, E. de. Uno sguardo d'insieme. L'opinione. In: GIARDA, A.; PERINI, A.; VARRASO, G. (coords.). La nuova giustizia penale tributaria. Assago (MI): CEDAM, 2016. p. 177 e 180, que "[...] o julgamento criminal foi adotado em nosso sistema jurídico como um elemento importante da autuação", onde "[...] a luta contra a evasão fiscal é feita com a ameaça de sanções penais", mas é errado pensar "[...] que a implementação de um sistema tributário racional e justo passe principalmente pela via criminal".
} 
Esse último deverá ser avaliado pelo juiz tributário no contexto de todo o compêndio probatório produzido pelas partes (ou ex officio) ${ }^{35}$, em que tanto mais examinado esse material amplo, mais aprofundada e calibrada na plataforma factual específica serão as atividades preliminares (e de tomada de decisão) realizadas pelo juiz, com vistas ao julgamento justo, em suas diversas formas. Porém, o julgamento penal irrevogável não será considerado como uma prova legal típica, mas como elemento circunstancial que o juiz tributário terá que apreciar junto com todos os outros elementos circunstanciais ${ }^{36}$, que serão separados (e, então, em geral) avaliados de acordo com sua percepção autônoma e prudente ${ }^{37}$.

In apicibus, o modelo de instrução probatória no processo tributário deve ser reconstruído na perspectiva de incluir em seu curso todos os meios probatórios anexados pelas partes ou realizados de ofício e, não apenas a evidência legal típica, mas, considerando também a chamada evidência atípica, que enriquece bastante o catálogo de provas, e que não pode ser considerado $a_{\text {priori }^{38}}$. Essa reconstrução é perfeitamente compatível com o disposto no art. 7 do Decreto Legislativo $\mathrm{n}^{\circ} 546$ de 1992, que exclui a admissibilidade do juramento e

35 Nesse sentido, Comm. trib. reg. Toscana, 20 abr. 2016, n. 704, com referência a uma sentença penal definitiva completa de absolvição (do representante legal da empresa), porque o fato não existe, em materia de delitos fiscais. Sublinha a sentença de que o juiz tributário não pode se limitar a detectar de forma não crítica a existência de um julgamento criminal que se tornou definitivo, a fim de aceitar as conclusões absolutas, mas deve fazer uma apreciação do conteúdo da tomada de decisão comparando-o com as outras evidências adquiridas durante o processo. Em uma perspectiva não muito diferente cita-se: Comm. trib. reg. Sicilia, 21 jan. 2015, n. 194, segundo o qual o juiz tributário pode sujeitar as constatações emergentes do processo criminal (relativos aos mesmos fatos) a uma avaliação jurídica lógica completamente independente em relação a esse último, na aplicação das regras específicas do rito tributário e, em particular, à (diferente) disciplina probatória.

36 Segundo Cass., sez. trib., 12 abr. 2017, n. 9442, o juiz tributário não pode negar, em princípio, que a apuração contida em sentença de absolvição, proferida nos termos do art. 425 do CPP, “[...] pode constituir uma fonte de evidência presuntiva, omitindo a avaliação autônoma dos elementos adquiridos em processos penais". No sentido sintônico, v. Cass., sez. VI, 28 jun. 2017, n. 16262, de acordo com a irrevogável sentença penal de absolvição de crime tibutário, como o fato não existe, representa uma evidência que pode ser livremente avaliada pelo juiz tributário, juntamente com as conclusões preliminares adicionais, também de natureza presuntiva.

37 Afirma POLI, R. Gli standard di prova in Italia. Giurisprudenza italiana, p. 2517 e ss., 2018, p. 2517 e 2518 , que o interesse da doutrina e da jurisprudência em relação aos padrões nos quais a prova pode ser considerado alcançada não foi particularmente generalizado na Itália. E o autor acrescenta que existem poucos estudos sobre o livre convencimento do juiz, “[...] princípio segundo o qual, no sistema jurídico italiano, o juiz avalia livremente as provas, ou seja, as provas cuja eficácia probatória não são determinadas por lei, mas precisamente pelo próprio juiz". Somente nos últimos vinte anos houve um debate mais intenso sobre os padões de prova, sob o perfil específico de determinação do nexo de causalidade. Nesse sentido, na ausência de disposições legais específicas, a jurisprudência italiana, do Tribunal de Cassação, acredita que no julgamento criminal se aplica o critério "além de qualquer dúvida razoável", enquanto que, no julgamento civil, o Tribunal é favorável ao critério "più probabile che no" ou da preponderância "de evidência" e da "probabilidade lógica prevalente". Esses critérios, segundo o autor, foram considerados basicamente gerais para fins de apuração dos fatos do processo, entendendo-se que, no julgamento penal, o critério de responsabilidade "além de qualquer dúvida razoável" tornou-se regra em 2006, conforme o art. 533, § $1^{\circ}$, CPP. Veja também NOBILI, M. Il principio del libero convincimento del giudice. Milano: Giuffrè, 1974, passim.

38 No mesmo sentido, cfr. COMOGLIO, L. P. Prove penali, "giusto processo" e poteri di acquisizione del giudice tributario. Diritto e pratica tributaria, v. 71, n. 4, p. 943-971, 2000, p. 952, sublinha que no sistema não existe uma regra de fechamento que "impõem a exaustividade do catálogo de provas e meios de prova admissíveis", onde existem aberturas claras para a atipicidade, tanto em termos objetivos quanto ontológicos, e em termos modais. 
do testemunho e aprecia totalmente a importância da instrução probatória como componente essencial da regulamentação do processo ${ }^{39}$, enquanto as provas atípicas não possuírem ${ }^{40}$ uma eficácia demonstrativa vinculada pela lei e, a esse respeito, não podem ser confundidas (ou equiparadas a) com as provas legais típicas ${ }^{41}$.

Nessa perspectiva, se o juiz tributário considerar que a sentença de absolvição penal final (produzida ritualmente em juízo) não possui alguma eficácia demonstrativa, com referência aos mesmos fatos controversos também no processo tributário, ele deve motivar adequadamente a decisão sobre esse ponto.

Nas mesmas conclusões estão, do ponto de vista do compêndio probatório, as sentenças penais que não são definitivas em relação ao processo tributário ainda pendente, onde os fatos materiais relevantes contestados (relevantes do ponto de vista físcal) são os mesmos, devendo-se excluir uma eficácia extensiva e automática. Nessa hipótese, o juiz tributário terá que avaliar, de tempos em tempos, a sentença penal produzida no julgamento, juntamente com todos os outros elementos indiciários, isto é, no quadro do complexo material probatório alegado pelas partes, ou agregado de ofício.

Além disso, há o problema de estabelecer qual é a eficácia demonstrativa com relação ao processo tributário, das evidências que são formadas durante as investigações preliminares ou até o julgamento penal. Também desse ponto de vista, a regra acima confirma a extensão máxima dos ativos probatórios que devem ser avaliados pelo juiz tributário, de acordo com sua apreciação prudente, dentro da estrutura geral das evidências anexadas pelas partes ou incluídas oficiosamente, sem prejuízo da necessidade de motivar adequadamente a sentença, nesse ponto.

39 Cfr. CAVALLONE, B. Riflessione sulla cultura della prova. Rivista italiana di diritto e procedura penale, $\mathrm{p}$. 947 e ss., 2008

40 Pense nas declarações e informações de terceiros, que não violam a proibição da prova típica de depoimento referido no art. $7, \S 4^{\circ}$, do d. Lgs. n $^{\circ} 546$, de 1992 e, portanto, são admitidos no processo tributário com eficácia demostrativameramente indiciária.

41 Nesse ponto, cfr. amplius COMELLI, A. Commento sull'art. 7 del D.Lgs. n. 546/1992. In: CONSOLO, C.; GLENDI, C. (coords.). Commentario breve alle leggi del processo tributario. Padova: Cedam, 2017. p. 96 e ss. 
A jurisprudência de legitimidade segue uma abordagem amplamente harmônica em relação à destacada acima ${ }^{42}$. A decisão do Tribunal de Cassação no 2916 , de $2013^{43}$ declara que um ato legitimamente assumido em processo penal e enviado à Administração Tributária “[...] passa a fazer parte integral do material probatório e circunstancial a ser avaliado pela Administração tributária”. Esse compêndio inclui interceptações telefônicas ${ }^{44}$ e as atas de "testemunhas coletadas pela Guardia di finanza" no contexto do procedimento penal e inseridos em um processo verbal de constatação (p.v.c. $)^{45}$.

De um ponto de vista diferente, a Corte, no arresto $n^{0} 27912$, de $2013^{46}$, examinou um caso em que o aviso de retificação, notificado para fins de IVA, se baseou no parecer oficioso fornecido pela P.M. em processos penais relativos aos mesmos fatos ${ }^{47}$. A esse respeito, ele afirma que, mesmo os resultados das investigações preliminares, realizadas em um tribunal penal, podem “[...] fornecer ao juiz, antes mesmo que a Administração realize sua atividade, elementos úteis e simultâneos de julgamento de natureza presuntiva e circunstancial, que podem, muito bem, contribuir para outros achados preliminares, ao apurar um fato controverso específico" ${ }^{\prime 4}$.

42 Afirma Cass. Sez. Trib., de 22 abr. 2015, $\mathrm{n}^{\circ}$ 8153, que fatos apurados e as evidências obtidas em um processo diferente (por exemplo, criminal ou administrativo) podem muito bem ser usados como indicações para serem submetidos a exame crítico no processo tributário, para serem entendidos como evidência atípica, capaz de fornecer elementos suficientes de julgamento, se e desde que não pare a comparação crítica com os outros resultados do processo. Essa comparação crítica é reservada ao juiz do julgamento e não pode ser criticada em termos de legitimidade, se for razoavelmente justificada. Cfr. Também comm. trib. reg. Marche, 12 fev. 2018, ${ }^{\circ}$ 44, em GT- Riv. giur. Trib., de 2018, 906 ss. com nota de I, Pellecchia, C. Setti della Volta, o valor probatório no processo tributário do atestado de veracidade e confiabilidade dos lançamentos contábeis efetuados no contrato de reestruturação da dívida.

43 Publicada em 7 fev. 2013, in GT - Riv. giur. trib., 2013, 385 ss., com comentário crítico de S. Armella, F. Di Luciano, L'utilizzo delle intercettazioni nel processo tributario e il delicato equilibrio con il diritto di difesa e il principio del giusto processo. Segundo os autores, o julgamento apresenta elementos críticos com referência ao perfil de defesa do contribuinte, bem como em relação à autonomia do processo penal em relação ao imposto, observado a diferente disciplina dos meios de prova.

44 Cfr. IORIO, A.; MECCA, S. Utilizzo delle intercettazioni nei procedimenti per reati tributari. Fisco, p. 2472 e ss., 2014.

$45 \mathrm{Na}$ mesma perspectiva, Cass., sez. trib., 8 abr. 2015, n. 6953, segundo as declarações de terceiros, os resultados da investigações realizadas contra outras empresas, os documentos policiais judiciais transmitidos pela Guardia di Finanza, as interceptações telefônicas, as cartas rogatórias dispostas em um tribunal criminal e qualquer outro ato que tenha sido legitimamente assumido na sede criminal, que são refletidos em um p.v.c. notificados ao particular e referidos no ato impositivo, são parte integrante do material circunstancial e probatório que o juiz tributário deve avaliar, e essa apreciação deve ser adequadamente motivada na sentença. 46 Publicado em 13 dez. 2013.

47 Enfatiza a decisão de que, no presente caso, a empresa sob investigação mantinha uma contabilidade formalmente regular, mas apresenta um excedente de custos em comparação com as receitas, suscetível de originar uma gestão de negócios totalmente não econômico. Portanto, a administração fiscal utilizou corretamente o c.t.u. contabilista preparado no julgamento penal, realizando um inventário analítico de todos os bens, comparando os preços de compra com os de revenda dos bens. Desse cálculo resultou a exposição na contabilização de receitas inexistentes.

48 Cass., 20 mar. 2013, n. 6918, in Corr. trib., 2013, 1847 ss., con nota di G. Doneddu, Esigenze di coordinamento per l'utilizzo nel processo tributario delle prove acquisite in sede penale, segundo as quais a administração tributária pôde usar, ao elaborar os avisos de autuação, um parecer técnico preparado pela 
Ainda mais explícita a orientação do Tribunal de Cassação em relação à eficácia, do lado tributário, da sentença que aplica a penalidade a pedido das partes, nos termos do art. 444 do CPP, afirma a decisão no 27196 de $2014^{49}$, que esse julgamento “[...] constitui evidência indiscutível e o juiz que pretender negar esse efeito probatório, tem o dever de explicar as razões pelas quais o acusado alegadamente admitiu sua responsabilidade inexistente e o juiz criminal confiou nessa admissão" ${ }^{, 50}$.

Nesse sentido, não seria um elemento meramente circunstancial, que o juiz tributário deveria avaliar de acordo com sua apreciação prudente, onde o ex. art. 444 do CPP poderia ser usado "como prova pelo juiz tributário no julgamento da legitimidade da autuação", "embora não esteja sujeito a uma decisão assistida pela efetividade da res judicata" ${ }^{51}$. Essa decisão não é caracterizada pela eficácia automática no lado probatório; no entanto, de acordo com a orientação expressa no arresto $\mathrm{n}^{\mathrm{o}} 20133$ de 2012 $2^{52}$, implica o reconhecimento de responsabilidade pelo acusado ${ }^{53}$,“[...] que constitui evidência indiscutível pelo menos de

Autoridade judicial durante o processo penal e adotado pela Guardia di Finanza. De acordo com o Tribunal que, no julgamento tributário, o juiz pode "[...] legitimamente basear sua condenação também nas evidências obtidas no julgamento criminal, mesmo que isso esteja destinado a terminar com uma decisão não executória contra as partes do julgamento civil, desde que tal evidência seja submetida pelo juiz tributário à sua própria avaliação independente". Sobre esse julgamento e sobre a orientação jurisprudencial que confirma, Cf. MONFREDA, N.; STELLA, F. Eficacia della sentenza penale nel processo tributario. Fisco, p. 4494 e ss., 2013.

49 Publicado em 22 dez. 2014. Com comentário sobre sentença, cfr. BECCALLI, C. Dal patteggiamento penale solo significativi elementi di prova per il giudice tributario. Fisco, p. 577 e ss., 2015.

50 A mesma frase é citada nas julgamentos da Cass., sez. trib., 23 mar. 2016, no 5699 e 10 jun. 2016, no 11955. O mesmo conceito é repetido, mutatis mutandis, no julgamento da Cass., sez. II civ., de 16 fev. 2016, $\mathrm{n}^{\circ} 2969$, com referência a um processo resultante da oposição perante o tribunal contra as medidas administrativas de rejeição preparadas pelo Ministério das Finanças em recursos interpostos contra quatro portarias, emitidas após disputas (contidas na ata lavrada pela Guardia di Finanza) para a percepção ilegal de somas a título de restituição de direitos niveladores agrícolas. Esse arresto confirma que o juiz do caso, se pretende negar o efeito probatório da sentença penal de aplicação da penalidade a pedido das partes, deve explicar adequadamente os motivos.

51 No entanto, o problema em questão parece ter perdido importância, pelo menos parcialmente, em consideração ao art. $13-b i s, \S 2^{\circ}$, do d.lgs. n. 74 del 2000, inserido pelo art. $12, \S 1^{\circ}$, do d.lgs. ${ }^{\circ} 158 / 2015$. De fato, de acordo com essa disposição, pelos crimes punidos pelo d. Lgs. $n^{\circ} 74$ de 2000 , a aplicação da pena conforme o art. 444 do CPP somente poderá ser solicitado pelas partes se a circunstância referida no art. 13-bis, $\S 1^{\circ}$, bem como o arrependimento ativo (as hipóteses referidas no art. $13, \S \S 1^{\circ}$ e $2^{\circ}$, da d. Lgs. $n^{\circ} 74$ de 2000 ). Mais precisamente, o pedido de barganha não pode ser apreciado, a menos que as dívidas físcais tenham sido extintas, com pagamento integral, incluindo multas administrativas e juros, antes da declaração de abertura da audiência de primeira instância. Sobre esse ponto, cfr. funditus MELIS, G. Sulla nuova disciplina degli effetti penali dell'estinzione del debito tributario e su taluni possibili interventi migliorativi. In: In: GLENDI, C. et al (coords.). Per un nuovo ordinamento tributario. Atti del convegno di Genova del 14-15 out. 2016, in occasione dei Novant'anni di Diritto e pratica tributaria. t. 2. Milano: CEDAM, 2019. p. 1481-1524. V. também AMADEO, R. Art. 13-bis del d.lg. n. 158/2015. In: NOCERINO, C.; PUTINATI, S. (coords.). La riforma dei reati tributari. Torino: Giappichelli, 2015.

52 Publicado em 16 nov. 2012.

53 No entanto, esse reconhecimento de responsabilidade é negado por CORVI, P. I rapporti tra accertamento tributario e accertamento penale. In: GIARDA, A.; PERINI, A.; VARRASO, G. (coords.). La nuova giustizia penale tributaria. Assago (MI): CEDAM, 2016. p. 490, como a jurisprudência penal constitucional. Cfr. também MANONI, E. Le sentenze penali di patteggiamento costituiscono elementi probatori da valutare nel giudizio tributario. Fisco, p. 3545 e ss., 2018. 
natureza presuntiva”. Esse último pode ser utilizado pelo juiz tributário como referência à triagem crítica, relativa à notificação de autuação realizada nos termos do art. $14, \S 4^{\circ}$ da Lei $\mathrm{n}^{\circ} 537$ de 1993, com referência aos recursos provenientes de infrações civis, criminais ou $\operatorname{administrativas}^{54}$.

\section{O MODELO DE CONEXÃO ENTRE AS INVESTIGAÇÕES PRELIMINARES E O} PROCESSO PENAL POR UM LADO, E A CONFECÇÃO DOS ATOS IMPOSITIVOS E O PROCESSO TRIBUTÁRIO, POR OUTRO, TENDENCIALMENTE DIFERENTE DO DOPPIO BINARIO "PERFEITO", SEM DEPENDÊNCIA PREJUDICIAL, COM A CIRCULAÇÃO AMPLA DE PATRIMÔNIO PROBATÓRIO

In apicibus, a autonomia do processo tributário em relação ao processo penal deve ser sublinhada e preservada positivamente, sem prejuízo do primeiro em relação ao segundo, em que o juiz criminal tem o poder de conhecimento incidental sobre a qualificação do imposto evadido e sobre a possível superação das liminares puníveis, se aplicáveis ${ }^{55}$.

Os dois ritos processuais são profundamente diferentes, não apenas do lado de sua evolução histórica e cultural, e seria irracional não reconhecer essas diferenças significativas, em respeito às suas manifestações concretas. Foi indicado pela doutrina ${ }^{56}$ "a inevitável diversidade de normas processuais que devem ser observadas, de acordo com as quais as repartições tributárias e os tribunais fiscais devem operar com o objetivo de recuperar os impostos evadidos, enquanto o juiz criminal deve aplicar sanções que afetem a liberdade pessoal do contribuinte".

Por outro lado, a atual estrutura legal é caracterizada por uma pluralidade de jurisdições e, esperançosamente, essa pluralidade pode ser mantida com vantagem também no futuro, apesar do debate atual sobre a possível (mas não desejável) criação de uma jurisdição

\footnotetext{
54 Cfr. CORSO, P. Obbligo per il P.M. di segnalare all'Agenzia delle entrate proventi illeciti suscettibili di imposizione fiscale. Corriere tributario, p. 325 e ss., 2016.

55 Cfr. TABET, G. Collegamento tra fattispecie tributaria e fattispecie penale: riflessioni di diritto processuale. Rassegna tributaria, p. 303 e ss., 2015. Sublinha Cass. pen., 14 fev. 2018, $\mathrm{n}^{\circ}$ 7020, que o processo penal nessa matéria de infrações fiscais é completamente autônomo no que respeita à apuração e ao processo fiscal e, com referência às mesmas infrações, e ius receptum que seja remetido ao juiz criminal "[...] a tarefa de determinar, o valor do imposto evitado, através de uma verificação que pode se sobrepor ou mesmo contradizer perante o juiz tributário".

56 Da LA ROSA, S. Orientamenti e disorientamenti in tema di rapporti tra norme penali e tributarie. Rivista di diritto tributario, v. 26, n. 1, p. 429 e ss., 2016, p. 431.
} 
única $^{57}$, o que, no entanto, não é permitido até que alguns artigos da Carta Constitucional sejam modificados.

Nesse modelo pluralista e dentro de uma organização racional de uma sociedade moderna, existe ampla autonomia de processos criminais em relação aos processos tributários, relacionados aos mesmos fatos materiais que são relevantes do ponto de vista fiscal. Nessa hipótese, as relações entre os dois complexos jurisdicionais podem ser enquadrados, por um lado, em termos de independência das ações e da separação, que não é absoluta, mas relativa $^{58}$, e, por outro, pelo menos abstratamente, da integração mútua ${ }^{59}$.

Sem poder investigar melhor essas diferenças aqui, anota-se o princípio da apreciação independente das provas por cada juiz, que abre caminho ao tópico, de grande profundidade teórica, da circulação de material probatório entre as diferentes jurisdições. A relevância e a transmigração das evidências também podem dizer respeito às evidências coletadas durante as investigações preliminares dos órgãos policiais judiciais e enviadas às repartições fiscais: os itens arrecadados e os documentos investigativos realizados durante essa fase estão sob sigilo investigativo, mas o magistrado pode autorizar sua transmissão às repartições fiscais e, também em respeito ao art. 329 do Código Penal italiano, não haver prejuízo para a investigação.

Além disso, a circulação do material probatório do processo penal para o tributário pressupõe, antes de tudo, a correta identificação do perímetro conceitual da prova ${ }^{60}$, que deve

57 Cfr. VILLATA, R. La giurisdizione amministrativa e il suo processo sopravviveranno ai "cavalieri dell'apocalisse"? Rivista di diritto processuale, v. 72, n. 1, p. 106 e ss., 2017. Veja-se também FABIANI, E.; TARTAGLIA POLCINI, A. (coords.). Sull'unità della giurisdizione in ricordo di F. Cipriani. Napoli: Edizioni Scientifiche Italiane, 2011, passim e, particularmente, FABIANI, E. Unità della giurisdizione, effettività della tutela giurisdizionale e possibili modelli di (istruttoria del) processo: riflessioni sparse. In: FABIANI, E.; TARTAGLIA POLCINI, A. (coords.). Sull'unità della giurisdizione in ricordo di F. Cipriani. Napoli: Edizioni Scientifiche Italiane, 2011. p. 123 e ss.

58 A questão da independência do processo penal em relação ao processo tributário é muito discutida (também) na doutrina francesa: cfr. DEBOISSY, F. Retour sur un principe controversé: l'indépendance des procédure pénale et fiscale. Revue de droit fiscal, a. 2014, n. 51-52, 18 dez. 2014, p. 9 . O autor salienta que, de acordo com a constante jurisprudência da Chambre Criminelle da Corte de cassação francesa, o princípio de independência se baseia na diferença de natureza e objeto dos procedimentos. E afirma que "[...] les juges ont déduit de cette différence de nature et d'object que les deux procédures se poursuivent en parallèle, à leur rythme propre, sans quel es résultats de l'une n'aient à être pris en compte par l'autre". Mas a jurisprudência do Conselho de Estado, acrescenta o autor, na p. 13, atribui ao princípio da independência entre os dois procedimentos um alcance menos absoluto do que o Tribunal de Cassação, destacando diferenças não insignificantes na respectiva jurisprudência, que justificam totalmente as propostas de reforma formuladas (p. 16). Em particular, tendo em vista a experiência jurisprudencial do Conselho de Estado, o juiz tributário deve levar em consideração o que foi decidido em substância pelo juiz criminal. Esse princípio, no entanto, não é entendido em um sentido absoluto e leva a soluções diferenciadas consideradas satisfatórias em geral.

59 Cfr. TESAURO, F. Ammissibilità nel processo tributario delle prove acquisite in sede penale. Rassegna tributaria, p. 323 e ss., 2015.

60 É possível consultar COMELLI, A. Commento sull'art. 7 del D.Lgs. n. 546/1992. In: CONSOLO, C.; GLENDI, C. (coords.). Commentario breve alle leggi del processo tributario. Padova: Cedam, 2017. p. 96 e ss. 
ser entendido, em princípio, como o "ponto principal da atividade judicial", "caracterizado por um vínculo inseparável com a sentença"61, embora submetido a uma avaliação potencialmente divergente e, em qualquer caso, independente do juiz ad quem.

A transmigração do compêndio probatório (das investigações preliminares) e do processo criminal para o tributário não determina nenhum automatismo, quanto à eficácia probatória em que as evidências coletadas no lado penal (por ex. interceptações por telefone) devem ser examinadas cuidadosamente pelo juiz tributário, que terá de atribuir a elas um valor indiciário e não o da prova legal típica.

Em outras palavras, não pode ser razoavelmente negada, pelo lado tributário, qualquer eficácia às provas legitimamente coletadas em processo penal (incluindo testemunho), mas as diferentes regras relativas à aquisição e avaliação da mesma evidência nos dois complexos jurisdicionais em questão devem ser consideradas. O juiz tributário deve se submeter a uma avaliação crítica escrupulosa e autônoma, de acordo com sua prudência, as provas provenientes das investigações preliminares e do julgamento criminal, e deve avaliá-las, no nível circunstancial, em consideração a todos os meios probatórios trazidos pelas partes ou agregadas de oficio, em relação aos fatos apresentados e contestados pelas mesmas partes, naquilo que for submetido a seu exame constitutivo.

Surge, portanto, um modelo de conexão entre o processo penal e o processo tributário que somente de modo reduzido pode ser chamado em termos do doppio binario "perfeito", fazendo-se necessário abandonar essa imagem que lembra uma metáfora ferroviária ${ }^{62}$ ultrapassada e completamente anacrônica, sendo preferível considerar, cuidadosamente, a transmigração de ativos probatórios de um processo para outro.

Esse arranjo afasta-se de um modelo de conexão entre os dois ritos processuais, em relação aos mesmos fatos materiais relevantes, exclusivamente em termos de separação acentuada, para convergir para um modelo que favorece a circulação do material probatório das investigações preliminares e do julgamento penal para a preparação dos atos impositivos e do processo tributário.

61 Così UBERTIS, G. Prova: II) teoria generale del processo penale. In: ENCICLOPEDIA giuridica Treccani. v. XXVIII. Roma: Ist. Enciclopedia Italiana, 2008. p. 1.

62 Cfr. SIENA, M. di. Doppio binario tra procedimenti tributario e penale: una metafora ferroviaria in crisi? Fisco, p. 4259 e ss., 2014. De acordo com esse autor, a via dupla é uma metáfora eficaz, mas todo o assunto está evoluindo ao longo de linhas estranhas ao esquema de autonomia absoluta e mútua e acredita que a frase que melhor capta o estado da arte é a de "convergências paralelas.". 
Tendo superado definitivamente o chamado doppio binario "perfeito"63, o modelo teórico em questão, de acordo com uma abordagem pragmática ${ }^{64}$, aumenta a ampla centralidade e necessária circulação de bens probatórios de um tribunal para outro. Ele responsabiliza o juiz tributário ${ }^{65}$, porquanto se solicita dele uma avaliação crítica e autônoma, em sede decisória, do contexto probatório proveniente das investigações preliminares e do registro criminal, nos mesmos fatos que são fiscalmente relevantes, em total conformidade com o princípio do contraditório entre as partes $^{66}$.

\section{NOTAS SObRe A EFICÁCia Não VinCUlante PARA O JUIZ PENAL, NO} LADO PROBATÓRIO DAS SENTENÇAS CONFECCIONADAS PELAS COMISSÕES FISCAIS E SOBRE A NÃO SUSPENSÃO DO PROCESSO TRIBUTÁRIO, DE ACORDO COM O ART. 39, § 1º-BIS DO D. LGS. Nº 546, DE 1992

Neste ponto da pesquisa é apropriado examinar os efeitos que podem ser atribuídos à qualquer sentença tributária, anterior à conclusão do julgamento penal, relativos à apuração dos mesmos fatos relevantes. Tais julgados não têm efeito vinculativo para o juiz penal ${ }^{67}$, onde existe um limite estreito para o uso automático dos resultados provenientes dos

63 Outros sinais de interdepência no sistema de relações entre processos em questão são refletidos na provisão de instituições de recompensa, que "visam obter satisfação de reivindicação tributária antes do julgamento criminal", assim sugere CORVI, P. I rapporti tra accertamento tributario e accertamento penale. In: GIARDA, A.; PERINI, A.; VARRASO, G. (coords.). La nuova giustizia penale tributaria. Assago (MI): CEDAM, 2016, p. 467, em referência ao art. 13 do d.lgs. n. 74 de 2000, modificado pelo art. 11, § $1^{\circ}$, do d.lgs. n. 158 de 2015. Acrescenta esse autor que a "[...] extinção da dívida tributária, incluindo juros e sanções administrativas, realizada antes da declaração de abertura da audiência", determina "[...] consequências importantes em nível criminal, configurando o pagamento integral desses montantes, conforme o caso, como condição de não punição ou como circunstância atenuante com efeito especial" (p. 467-468 ). Sobre isso, v. também PERINI, A. La riforma dei reati tributari. Dir. pen. e proc., p. 31 e ss., 2016, sublinha a escolha da política penal que caracterizou fortemente a reforma dos crimes fiscais mencionados d.lgs. n. 158/2015, no sentido de atribuir eficácia extintiva do crime ao pagamento da dívida tributária.

64 Cfr. FRANSONI, G. Rilevanza processuale penale del "fatto fiscale" e rilevanza processuale fiscale del "fatto penale". Rivista di diritto tributario, v. 26, n. 1, p. 1 e ss, 2016, e, especialmente, 22.

65 Salienta, em um sentido breve GUIDI, D. I rapporti tra processo penale e processo tributario ad oltre dieci anni di distanza dal D.Lgs. n. 74 del 2000. Dir. pen. e processo, p. 1384 e ss., 2012, a "forte responsabilidade do juiz tributário", o qual "[...] deve reavaliar criticamente de maneira autônoma, à luz dos princípios e critérios que regem a conduta do rito tributário, os resultados preliminares do julgamento criminal", não pode basear sua condenação nos fatos do caso exclusivamente em consideração a um julgamento criminal irrevogável, referente aos mesmos fatos.

66 Sobre a circulação de material probatório e o princípio contraditório, cfr. MARCHESELLI, A. La circolazione dei materiali istruttori dal procedimento penale a quello tributario. Rassegna tributaria, $\mathrm{p}$. 83 e ss., 2009.

67 Cfr. RANDAZZO, F. Manuale di diritto tributario. Torino: Giappichelli, 2018. p. 308. 
processos em que existem limitações no lado probatório, como ocorre na tributação anterior, no sentido especificado ${ }^{68}$.

O julgado formado após a decisão tributária pode ser apenas uma das constatações livremente apreciadas pelo juiz criminal, de fato e de direito ${ }^{69}$, de acordo com o princípio do livre convencimento ${ }^{70}$. Em outras palavras, as sentenças transitadas em julgado em matéria tributária podem ser acessadas na audiência e avaliadas com o objetivo de comprovar o fato nelas verificadas, nos termos do art. 238-bis do $\mathrm{CPP}^{71}$, mas não são vinculativas para o juiz criminal, com a mesma conclusão no que se refere às sentenças das comissões fiscais que não têm autoridade de coisa julgada ${ }^{72}$, e podem ser acessadas, em casos criminais, para fins de avaliação independente das evidências ${ }^{73}$.

Em outros aspectos, a regulamentação da suspensão do processo tributário, no que diz respeito, não pode ser considerada alterada, com referência à hipótese do processo penal pendente, conquanto os fatos relevantes sejam os mesmos, à luz do Decreto Legislativo $\mathrm{n}^{\mathrm{o}}$ 156, de 24 de setembro de $2015^{74}$, cujo art. $9^{\circ}$ introduziu uma série de modificações no texto

68 Do ponto de vista da eficácia das sentenças fiscais em relação ao julgamento criminal, ele diz de certa forma compartilhável. MASTROGIACOMO, E. Commento sull' art. 20 del d.lgs. n. 74/2000. In: MOSCHETTI, F. (coord.), Commentario breve alle leggi tributarie. t. II. Padova: CEDAM, 2011, p. 662, que no Código Penal vige o princípio do livre convencimento do juiz, o qual é difícilmente conciliável com a presença de julgamentos vinculativos.

69 Compartilha essa visão LA ROSA, S. Principi di diritto tributario. Torino: Giappichelli, 2016. p. 425.

70 Afirma Cass. pen., 13 jun. 2019, n. 26196, que o percentual de acréscimo resultante de estudos setoriais, para fins de IVA contribui para avaliar o excedente do limite de multa com referência ao imposto evadido, em relação ao crime de declaração omitida nos termos do art. 5 de d.lgs. $n^{\circ} 74$ de 2000, juntamente com outros elementos ocorridos no ano analisado, como as vendas abaixo do custo, a falta de confiabilidade das contas da empresa, a conta de caixa negativa e o valor significativo das operações de financiamento na conta do acionista, que suportam a hipótese de altas vendas em negro.

71 No mesmo sentido, cfr. Cass. pen., 15 fev. 2016, n. 6113, segundo o qual o que emerge "das decisões do juiz tributário não afeta os efeitos penais, uma vez que as decisões do mesmo juiz são, no máximo, avaliáveis, se definitivas”. Cass. pen., 28 nov. 2017, n. 53636, que devem ser negadas as sentenças do juiz tributário e as do juiz administrativo que vinculam o efeito do julgamento criminal, onde a ordem processual, na mesma situação do art. 238-bis do CPP, limita-se a permitir a aquisição no julgamento de sentenças que se tornaram irrevogáveis, mas prevê que sejam avaliadas com o objetivo de provar o fato nelas verificado" (v. também Cass. pen., 19 maio 2017, n. 25008). Portanto, prevalece a apreciação autônoma dos fatos nele reconstruídos, uma vez que é possível um resultado de tomada de decisão diferente das conclusões surgidas em outros procedimentos.

72 Afirma com clareza Cass. pen., 18 nov. 2013, n. 46165, “[...] que a verificação pelo juiz criminal possa se sobrepor ou mesmo contradizer o que foi realizado perante o juiz fiscal, porque no tribunal criminal deve haver uma prevalência de dados factuais reais com relação aos critérios formais que caracterizam o sistema tributário, uma vez que nenhuma decisão preliminar tributária pode ser configurada". Esse claro contraste entre os "dados factuais reais" e os "critérios formais da natureza", que conota as diferencas radicais entre a sede criminal e tributária, destacou aqui um sentido que não pode ser totalmente compartilhado, onde a identificação da capacidade contributiva do individuo sujeito a investigações fiscais não pode ser meramente abstrata e desvinculada da situação de fato real e nem mesmo ligada apenas a elementos formais.

73 No sentido sintônico, v. BELLAGAMBA, G.; CARITI, G. Il sistema delle sanzioni tributarie. Milano: Giuffrè, 2011, p. 286, segundo o qual a sentença preparada pelo juiz tributário pode ser apreciada no julgamento apenas como um dos elementos livremente passíveis de avaliação pelo juiz e, além disso, com cautela particular. 74 Realizado, no que nos diz respeito, na implementação do artigo 10, parágrafo $1^{\circ}$, alíneas a e b da lei no 23 de 11 mar. 2014, que delegou ao governo intervir para alcançar "um sistema tributário mais equitativo, transparente 
do Decreto Legislativo $\mathrm{n}^{\mathrm{o}} 546$ de 1992, tendo em vista, aumentar a "funcionalidade da jurisdição fiscal". O art. $9^{\circ}, \S 1^{\circ}$ do Decreto Legislativo $n^{\circ} 156$ de 2015 inseriu dois parágrafos no texto do art. 39 do Decreto Legislativo ${ }^{\circ} 546$ de 1992 e, precisamente, o $\S 1^{\circ}$ bis e o $\S 1^{\circ}$ $t r^{75}$, por meio do qual foram ampliadas, de forma significativa, as hipóteses de suspensão do processo tributário com considerável impacto sistemático ${ }^{76}$.

A nova hipótese de suspensão, referida no $\S 1^{\circ}$ bis do art. 39 , codifica a chamada “prejudicialidade interna" e incorpora a orientação jurisprudencial de legitimidade favorável à extensão do pedido do art. 295 do CPC, com vistas a permitir suspensões necessárias nas relações entre processos fiscais, na presença de disputas entre as mesmas partes, ligadas por um vínculo de prejudicialidade ou de dependência substanciais ${ }^{77}$. Portanto, vem codificada uma abordagem jurisprudencial que favorece a coordenação dos julgamentos e a coerência entre os julgados, mesmo que se verifique uma estagnação temporária do processo dependente, isto é, sua paralisação temporária, que pode durar um período mais longo, enquanto se aguarda a sentença transitada em julgado, com a causa prejudicial. Mas esse fenômeno só pode ocorrer dentro da jurisdição tributária, no qual se espera que a res judicata possa explicar uma eficácia confirmatória positiva em outras disputas tributárias, entre as mesmas partes, conectadas pelo nexo ut supra evidenciado.

Do ponto de vista da conexão entre o processo penal e fiscal, sequer é revelada a introdução do $\S 1^{\circ}$, no texto do art. 39 do Decreto Legislativo ${ }^{\circ} 546$ de 1992. De fato, prevê a suspensão acordada entre as partes, na dependência de um procedimento consensual contra a dupla tributação, de acordo com as convenções internacionais ou com um procedimento consensual iniciado, da mesma forma que a Convenção de Arbitragem no 90/436/CEE,

e orientado para o crescimento" estabelecendo os princípios e critérios orientadores relacionados.

75 Cfr. GAFFURI, A. Commento sull'art. 39 del d. Lgs. n. 546/1992. In: TESAURO, F. (coord.). Codice commentato del processo tributario. Assago (MI): Utet Giuridica, 2016. p. 580 e ss.; LOCONTE, S. Commento sull'art. 39 del d.lgs. n. 546/1992. In: CONSOLO, C.; GLENDI, C. (coords.). Commentario breve alle leggi del processo tributario. Padova: Cedam, 2017. p. 555 e ss.

76 Nesse sentido cfr. CONSOLO, C.; STELLA, M. Commento sull'art. 39 del d.lgs. n. 546/1992. In: GLENDI, C.; CONSOLO, C.; CONTRINO, A. (coords.). Abuso del diritto e novità sul processo tributario. Milano: Ipsoa, 2016. p. 188.

77 Em uníssono, cfr. CONSOLO, C.; STELLA, M. Commento sull'art. 39 del d.lgs. n. 546/1992. In: GLENDI, C.; CONSOLO, C.; CONTRINO, A. (coords.). Abuso del diritto e novità sul processo tributario. Milano: Ipsoa, 2016. p. 188 e 189, para os quais a disposição em questão não pode ser concebida apenas como um ato de reconhecimento da "lei viva", no entanto, nem sempre unívoco. Pelo contrário, para esses autores, o propósito sistemático do art. $39, \S 1^{\circ}$. bis do d.lgs. n. 546 de 1992 é significativo e deve ser devidamente enfatizado, em termos da aplicabilidade do art. 295 do CPC ao processo tributário, que na doutrina não é pacífica e "[...] tem suas raízes no tema do objeto do processo tributário e no escopo da coisa julgada que o conclui”. 
concluído pelos estados membros em Bruxelas, em 23 de julho de $1990^{78}$, ratificado e aplicado na Itália pela Lei $n^{0} 99$ de $1993^{79}$.

\section{A PLENA COMPATIBILIDADE DO MODELO DE ADAPTAÇÃO PROPOSTO EM RELAÇÃO À VIS EXPANSIVA DA TRANSLATIO ACTIONIS (OU IURISDICTIONIS) CODIFICADA NO ART. 59 DA LEI N 69, DE 2009}

Em um arranjo caracterizado pela pluralidade de jurisdições ${ }^{80}$, apesar de ser o conceito de jurisdição abstratamente unitária $^{81}$, surge o problema de identificar como elas se relacionam, respeitando suas manifestações concretas e de suas diferentes evoluções históricas $^{82}$. As jurisdições são separadas e autônomas, mas essa autonomia não é absoluta e, longe de serem completamente desconectadas e separadas umas das outras, elas manifestam, em certa medida, a existência de integração mútua e racional, com o objetivo de garantir,

78 A convenção refere-se à "eliminação da dupla tributação no ajuste dos lucros das empresas associadas", na qual é permitido fazer referência a COMELLI, A. L'armonizzazione (e il ravvicinamento) fiscale tra lo "spazio unico europeo dell'iva", la direttiva del Consiglio "contro le pratiche di elusione fiscale" e l'abuso del diritto. Diritto e pratica tributaria, v. 89, n. 4, p. 1397-1436, 2018. p. 1428 e 1429.

79 A reforma do d.lgs. $n^{\circ} 546$ de 1992, operada pelo d.lgs. no 156 de 2015 e, referido no art. 9, $\S 1^{\text {o }}$, alínea u, também revisou o artigo 49 de d.lgs. no 546 del 1992, expandindo desse último a referência ao art. 337 do CPC das disposições não aplicáveis e os recursos das sentenças das comissões físcais. Em outras palavras, enquanto anteriormente não era aplicável o art. 337 do CPC como da citada obra supra, também são aplicáveis as disposições desse artigo, cujo $\S 2^{\circ}$ rege a hipótese em que, contra uma sentença que já se tornou definitiva, é proposta uma apelação extraordinária e, na dependência da sentença, a res judicata contida no acórdão impugnado e invocado em outro julgamento, dependente do primeiro [cfr., no mesmo sentido, CONSOLO, C.; STELLA, M. Commento sull'art. 39 del d.lgs. n. 546/1992. In: GLENDI, C.; CONSOLO, C.; CONTRINO, A. (coords.). Abuso del diritto e novità sul processo tributario. Milano: Ipsoa, 2016, p. 226 e 227]. O juiz depara-se com a alternativa entre cumprir a decisão com a autoridade da própria coisa julgada e sujeita a recurso extraordinário (se ele acredita que a apuração feita no caso prejudicial tem excelentes oportunidades para se estabilizar) ou suspender o processo prejudicado aguardando a decisão sobre o recurso extraordinário.

80 No sistema jurídico atual, a pluralidade de jurisdições garante que, para toda situação legalmente relevante, exista uma proteção (somente essa proteção) no lado do julgamento, como actus trium personarum, no qual as partes e o juiz estão envolvidos. Em outras palavras, não pode haver dupla proteção das partes perante um juiz pertencente a duas jurisdições diferentes, onde a proteção de um direito específico (ou interesse legítimo) não pode corresponder à identificação de um único juiz a quem a jurisdição é devotada. Em virtude do art. $24, \S 1^{\circ}$, da Constituição.

81 Com referência ao direito romano, é visto em NICOSIA, G. Giurisdizione nel diritto romano, In: DIGESTO delle discipline privatistiche. Sezione civile. v. IX. 2. reimpr. Assago (MI): Utet Giuridica, 2013. p. 120 e ss.

82 Em relação ao vínculo entre o processo civil e o processo tributário, codificado no art. $1, \S 2^{\circ}$ do d.lgs. n. 546 de 1992, sem pretenção de exaustividade, cfr. as contribuições fundamentais de CHIZZINI, A. I rapporti tra codice di procedura civile e processo tributario. In: TESAURO, F. (coord.). Il processo tributario. Torino: Utet, 1998, p. 3 e ss.; GIOVANNINI, A. Giustizia civile e giustizia tributaria: gli archetipi e la riforma. Rassegna tributaria, p. 14 e ss., 2014, p. 14 e 15; GLENDI, C. Rapporti tra nuova disciplina del processo tributario e codice di procedura civile. Diritto e pratica tributaria, v. 71, n. 6, p. 1700-1711, 2000; Id. Rapporti tra regole generali del processo civile e disciplina speciale del processo tributario. Corriere tributario, p. 3067 e ss., 2007; Id. Nuove disposizioni generali del codice di procedura civile e processo tributario. Corriere tributario, p. 2561 e ss., 2010; Id. Nuova disciplina del processo civile di cognizione e processo tributario. Corriere tributario, p. 2954 e ss., 2010; MARELLO, E. Commento sull'art. 1 del d.lgs. n. 546/1992. In: TESAURO, F. (coord.). Codice commentato del processo tributario. Assago (MI): Utet Giuridica, 2016; MICCINESI, M. Commento sull'art. 1. In: BAGLIONE, T.; MENCHINI, S.; MICCINESI, M. Il nuovo processo tributario. Commentario. Milano: Giuffrè, 1997. p. 5 e ss. 
através do exercício de uma atividade (precisamente jurisdicional) ${ }^{83}$, a proteção de direitos e interesses legítimos.

As interrelações entre jurisdições singulares evoluíram ${ }^{84}$, no sentido de que suas diferenças não são tão sutis, superando definitivamente a impermeabilidade, a favor de um modelo com base na transferência de uma jurisdição para outra, através da circulação da ação, disciplinada positivamente no art. 59 da Lei $n^{0}$ 69, de 2009. Essa disposição tem uma relevância muito significativa, em termos de processo tributário, do ponto de vista da

83 Cfr. a rubrica do art. 2907 do CC, denominada "attività giurisdizionale". Sobre o ponto, v. sobretudo CHIZZINI, A. La tutela giurisdizionale dei diritti. Milano: Giuffrè, 2018, passim; Id. La domanda giudiziale e il suo contenuto. Milano: Giuffrè, 2018. passim; MANDRIOLI, C. Giurisdizione (in generale). In: DIGESTO delle discipline privatistiche. Sezione civile. v. IX. 2. reimpr. Assago (MI): Utet Giuridica, 2013. p. 128, segundo o qual as diferentes opiniões sobre jurisdição mantidas na doutrina parecem concordar que a jurisdição consiste em uma atividade e, em particular, uma atividade legal, isto é, em "[...] uma série de atos jurídicos que constituem o exercício de tantos poderes até um ato final que produz certos efeitos jurídicos". À luz do art. 2907 do CC, pois, "[...] jurisdição é indiretamente identificada como um atributo da proteção de direitos", enquanto o art. 24 da Constituição esculpe "agir em juizo" com base na proteção de direitos e interesses legítimos.

84 No que se refere ao processo administrativo e, em particular, ao seu código, a forma de conexão com o processo tributário deve levar em consideração o apelo estabelecido positivamente, com eficácia erga omnes, dos regulamentos e atos gerais, em termos de legitimidade, à luz do art. $7^{\circ}, \S 5^{\circ}$ do d.lgs. n. 546 de 1992 [veja-se ALFANO, R. Il potere di disapplicazione del giudice nel processo tributario. Rassegna tributaria, p. 830 e ss., 2007, e, particularmente, 840-844; COMELLI, A. Commento sull'art. 7 del D.Lgs. n. 546/1992. In: CONSOLO, C.; GLENDI, C. (coords.). Commentario breve alle leggi del processo tributario. Padova: Cedam, 2017. p. 96 e ss.; FANNI, M. Commento sull'art. 7 del d.lgs. n. 546/1992. In: TESAURO, F. (coord.). Codice commentato del processo tributario. Assago (MI): Utet Giuridica, 2016. p. 164 e ss.; FRANSONI, G. La disapplicazione dei regolamenti e degli atti generali. In: TESAURO, F. (coord.). Il processo tributario. Torino: Utet, 1998. p. 119 e ss.]. Além disso, essa disposição não é colocada no plano (da repartição) da jurisdição, mas sim sobre o plano completamente diverso da cognição. $\mathrm{O}$ art. $7^{\circ}, \S 5^{\circ}$, no entanto, deve ser lido e interpretado em relação ao disposto no art. $2^{\circ}, \S 3^{\circ}$ da d.lgs. $n^{\circ} 546$ de 1992 , de acordo com o qual o juiz tributário tem o poder de resolver "incidentalmente" do qual depende a solução da disputa, com a exclusão de "perguntas relacionadas a uma queixa falsa e ao estado ou capacidade das pessoas, além da capacidade de comparecer no tribunal". Essas duas disposições não entram em conflito entre si, onde a primeira pode ser interpretada como uma especificação da segunda e está incluída nela. Enquanto o juiz administrativo pode revisar os regulamentos e atos gerais principalmente, o juiz tributário pode revisá-los exclusivamente como tantum de incidente, com eficácia inter partes, desde que relevantes para efeitos da decisão, ou seja, se constituem a condição do ato impugnado, cujos defeitos são consequências da ilegalidade desses atos. Consequentemente, o art. $7^{\circ}, \S 5^{\circ}$, traça a linha de separação, em parte, aqui entre o conhecimento incidental do juiz tributário, suscetível de desaplicar regulamentos e atos gerais, no que diz respeito principalmente ao conhecimento, devolvido em sua plenitude exclusivamente ao juiz administrativo, Cfr. TABET, G. Una giurisdizione speciale alla ricerca della propria identità. Rivista di diritto tributario, v. 19 , n. 1, p. 32 e ss., 2009, p. 32-35, em que o autor investiga a relação entre jurisdição tributária e administrativa. V. também RUSSO, P. Il riparto della giurisdizione fra giudice tributario e giudice amministrativo e contabile. In: BASILAVECCHIA, M.; TABET, G. (coords.). La giurisdizione tributaria nell'ordinamento giurisdizionale. Atti del convegno di Teramo, 22 e 23 nov. 2007. Bologna: Gedit, 2009. p. 91 e ss. Da mesma maneira que acima, a forma de conexão entre o processo civil e tributário é positivamente esculpida no d. Lgs. ${ }^{\circ} 546$ de 1992 e em particular, como o art. $1^{\circ}$, § $2^{\circ}$, embora a mesma conclusão não possa ser alcançada com referência ao formulário de ligação entre o processo administrativo e tributário apesar das disposições art. $7^{\circ}, \S 5^{\circ}$, que opera, como já observado, no nível diferente de cognição. Completamente pleonástico, então, e a disposição mencionada no art. $7^{\circ}$, $\S 4^{\circ}$, do estatuto do contribuinte (L. $n^{\circ} 212$ de 2000), que nada acrescenta à divisão de jurisdição entre os tribunais administrativos e tributários, como evidenciado pela referência abstrata às "premissas", estabelecidas em outros lugares e regidas pelo exercício da ação (cancelamento) perante o juiz administrativo. No nível processual, portanto, essa disposição deve ser considerada completamente inútil e inadequada para ajudar a identificar o vínculo exato entre os dois ritos processuais em termos. 
identificação precisa do conceito de jurisdição ${ }^{85}$, em uma perspectiva dinâmica, que considera cuidadosamente a evolução que ocorreu in parte qua.

Nesse sentido, o conceito de jurisdição é cada vez mais destacado de uma reconstrução conectada a uma manifestação (agora anacrônica) da soberania do Estado; além disso, já criticou a doutrina, o conceito de função ${ }^{86}$, devendo-se preferir dimensão, entendida em sentido figurado, na qual elas vêm tutelar em concreto situações subjetivas ${ }^{87}$, com uma série de corolários que atendam à sua divisão em plexos singulares e aos nexos de ligação entre esses últimos pelos quais opera um fenômeno de verdadeira e própria osmose jurídica, garantido por translatio actionis (o iurisdictionis) ${ }^{88}$. Como estabelecido na sentença da Corte

85 Em termos de jurisdição tributária, cfr. inter alios CICALA, M. La giurisdizione tributaria. Fisco, p. 2047 e ss., 2005; FICHERA, F. L'oggetto della giurisdizione tributaria e la nozione di tributo. Rassegna tributaria, p. 1059 e ss., 2007; GLENDI, C. La giurisdizione tributaria nel prisma dell'ordinamento. Diritto e pratica tributaria, v. 81, n. 2, p. 315 e ss., 2010; RANDAZZO, F. I confini della giurisdizione tributaria sul versante della riscossione e dell'esecuzione forzata tributaria. In: BASILAVECCHIA, M.; TABET, G. (coords.). La giurisdizione tributaria nell'ordinamento giurisdizionale. Atti del convegno di Teramo, 22 e 23 nov. 2007. Bologna: Gedit, 2009. p. 49 e ss.; TABET, G. La lunga metamorfosi della giurisdizione tributaria. GT - Rivista di giurisprudenza tributaria, 2014, p. 465 e ss.; TESAURO, F. Giurisdizione tributaria e diritto comunitario. GT - Rivista di giurisprudenza tributaria, p. 465 e ss., 2007.

86 Cfr. SATTA, S. Giurisdizione (nozioni generali). In: ENCICLOPEDIA del diritto. v. XIX. Milano: Giuffrè, 1970, p. 218 e 219, que critica, do ponto de vista metodológico, a definição de jurisdição em função do estado, “[...] cujo conteúdo específico está sendo procurado, em oposição a outras funções especiais”. Essa definição, segundo o autor, como outros citados, não é incorreta em si mesma, mas tem um caráter convencional, isto é, é o resultado de uma opção entre as várias possíveis e, portanto, é de alguma forma arbitrária ou, de qualquer forma, parcial, pois não é provável que compreenda o proprium conceito do exame. Nessa perspectiva, a jurisdição não seria uma função (caso contrário, correria o risco de privar a ordem "da visão unida") e a referência ao estado faria setido apenas em relação ao conceito de poder, onde a jurisdição envolve poder. Acrescenta o autor que o termo "jurisdição", em textos legislativos, nunca é usado em sentido absoluto, ou seja, como uma qualificação abstrata, mas em relação a uma atividade concreta disciplinada em seu desempenho (pense na atividade "jurisdicional", nos termos do art. 2907 por CC). Além disso, uma qualificação abstrata está contida na Constituição e corresponde ao termo "justiça" (por ex., ver art. 101), com uma identificação com a justiça.

87 GLENDI, C. La giurisdizione nel quadro evolutivo di nuovi assetti ordinamentali. Giusto processo civile, p. 337 e ss., 2009, p. 338, 341 e 343, prefere sublinhar a evolução da jurisdição em direção ao "local" em que as situações subjetivas são protegidas, com a abertura da jurisdição italiana no exterior, "[...] precisamente por causa de uma disponibilidade muito ampla para as necessidades de proteção que costumamos fazer uso aqui". Em outras palavras, de acordo com o autor, o mencionado conceito de "lugar" deve ser entendido como precisão, "[...] como um local de acolhimento e proteção de situações subjetivas, mesmo que, entre outras coisas, elas estejam progressivamente crescendo além de muitas precondições rígidas".

88 Cfr. BALENA, G. La nuova pseudo-riforma della giustizia civile (un primo commento della 1.18 giugno 2009, n. 69). Giusto processo civile, p. 756 e ss., 2009; GLENDI, C. "Translatio iudicii" tra diverse giurisdizioni: problemi pratici e prospettive "in apicibus" (con particolare riguardo alla giurisdizione tributaria). GT - Rivista di giurisprudenza tributaria, p. 557 e ss., 2007; Id. La circolarità dell'azione tra le diverse giurisdizioni dell'ordinamento nazionale. Corriere tributario, p. 2655 e ss., 2009; Id. La giurisdizione nel quadro evolutivo di nuovi assetti ordinamentali. Giusto processo civile, p. 337 e ss., 2009 e republicado em Diritto e pratica tributaria, 2009, n. 1, p. 773 e ss.; Id.La circolarità dell'azione tra le diverse giurisdizioni dell'ordinamento nazionale. Diritto e pratica tributaria, v. 81, n. 1, p. 121-143, 2010; Id.Oggetto del processo e "translatio iurisdictionis". Diritto e pratica tributaria, v. 84, n. 1, p. 69 e ss, 2013. V. também, sem pretensão de exaurir, CONSOLO, C. Translatio, regolamento, ragionevole durata e disciplina (anch'essa ragionevole) delle "liti" sulla giurisdizione. Corriere giuridico, p. 351 e ss., 2011; Id. Translatio iudicii e compiti del regolamento di giurisdizione, con esame anche dell'incidenza scoordinata del nuovo "codice della giustizia amministrativa". Corriere giuridico, p. 758 e ss., 2010; MONTELEONE, G. Difetto di giurisdizione e prosecuzione del processo: una confusa pagina di anomalie processuali, Rivista di diritto processuale, v. 65, n. 2, p. 271 e ss., 2010; RICCI, E. F. Declinatoria di giurisdizione e (così detta) translatio iudicii. Rivista di diritto processuale, v. 63, n. 3, p. 
Constitucional $n^{\circ} 139$, de $2019^{89}$, os sistemas processuais civis, administrativos, contábeis e tributários são distintos, mas se comunicam entre si, como os translatio iudicii referidos na disposição acima mencionada.

É particularmente importante para nós o $\S 5^{\circ}$ do art. 59 da Lei $n^{\circ} 69$, de 2009 , o qual afirma que, se a questão for levantada antes do juízo ad quem, as evidências reunidas perante o juízo a quo "po “podem ser valoradas como argumentos de prova". Ex positivo iure, portanto, a circularidade da ação ${ }^{91}$, regida pelos quatro primeiros parágrafos do art. 59, produz efeitos relevantes sob o panorama probatório, isto é, com referência às evidências reunidas no juízo sem jurisdição. E bem, o quinto parágrafo esculpe a regra segundo a qual essas provas podem circular no juízo ad quem, e esse último poderá valorar, de acordo com sua apreciação prudente (mas não discricionária), não como evidência, mas como um único tópico de prova, embora a diferença entre esses dois $\operatorname{conceitos}^{92}$ seja um pouco obscura e até incerta.

Consequentemente, o juiz ad quem deverá examinar todo o resumo probatório, incluindo as evidências reunidas perante o juiz a quo, que o primeiro poderá usar como premissa para inferências probatórias, com o objetivo de formular conclusões sobre os fatos relevantes (e disputas entre as partes) para a decisão final sobre a disputa. Portanto, o art. 59, $\S 5^{\circ}$, consagra o princípio fundamental segundo o qual a circulação da ação também postula a circulação das provas recolhidas no órgão jurisdicional a quo e admite expressamente que essas podem ser avaliadas por um juiz pertencente à outra jurisdição, como fontes de conhecimento e convicção.

O citado art. 59, no entanto, não é incompatível com o modelo de conexão entre o processo penal e o processo tributário proposto neste ensaio e, de fato confirma, graças à visão abrangente que caracteriza essa tal disposição, que as provas colhidas no plexo jurisdicional podem circular e ser valoradas em outro plexo. Em conformidade com o modelo de instrução probatória que caracteriza o processo, nesse último plexo e no contraditório entre as partes, o juiz ad quem pode (rectius: deve) considerar tais meios de prova, no sentido

693 e ss., 2008.

89 Publicada na data de 6 jun. 2019.

90 Ou seja, o juiz sem jurisdição.

91 Com referência a uma hipótese de translação a favor da comissão fiscal competente, em matéria de imposto sobre hipotecas, cfr. Trib. Como, 16 jul. 2015, n. 1218. Cfr. também Cass., sez. un., 18 nov. 2015, n. 23539, que afirma o "[...] redimensionamento progressivo da instituição de jurisdição (e abordagem correlativa da jurisdição), à luz do princípio da duração razoável do processo". O Tribunal acrescenta que o princípio da preservação dos efeitos que o pedido teria produzido se apresentado ao juiz competente for implementado, permitindo que as partes continuem perante um segundo juiz o processo iniciado anteriormente fora da jurisdição e, como corolário, "isso resulta em uma redução do processo desde a aplicação até a decisão final".

92 A referência é aos conceitos de prova e de argumentos de prova. 
próprio e atribuir a eles um valor demonstrativo em termos de fontes de conhecimento e convicção.

\section{A DESNECESSÁRIA SUSPENSÃO DO PROCESSO PENAL (NEM MESMO DE IURE CONDENDO) NO AGUARDO DA DETERMINAÇÃO DO IMPOSTO DEVIDO PELO JUIZ TRIBUTÁRIO, COM SENTENÇA TRANSITADA EM JULGADO}

Da mesma forma, o art. $1^{\mathrm{o}}$, alínea $f$, do Decreto Legislativo $\mathrm{n}^{\mathrm{o}} 74$, de 2000 , o imposto evadido e identificado com referência ao conceito de imposto (atualmente) devido ${ }^{93}$, cuja quantificação, do ponto de vista do direito penal, pode muito bem ser diferente daquela feita pelo juiz tributário ${ }^{94}$ e se reflete sobre a possível superação dos limites de punição, quando previstos, em relação aos tipos individuais do crime ${ }^{95}$. A determinação potencialmente discordante do imposto devido depende, por um lado, da especificidade do conceito de multas por sonegação ${ }^{96}$ e, por outro lado, pelos diversos instrumentos disponíveis ao juiz para fins de

\footnotetext{
93 Mais precisamente, se a declaração foi enviada, o imposto evadido é igual à diferença entre o valor real vencido e o imposto indicado na declaração; se esse último não tiver sido apresentado, o imposto evadido coincide com o valor total do imposto devido: cfr. o art. 1, alínea $f$, do d.lgs. n. 74 de 2000.

94 Afirma Cass. pen., 22 set. 2016, n. 39379, in GT - Riv. giur. trib., 2017, 247 ss., com nota de C. Consorti, No alla misura dell'imposta evasa senza costi presumibili, com referência ao crime de declaração infiel, de que o imposto evadido consiste em todo o imposto recebido e deve ser determinado em consideração à evidência probatória adquirida no processo criminal, com base na análise e no contraste entre receitas e custos dedutíveis de impostos do exercício, fazendo com que os "[...] dados fatuais reais prevaleçam sobre os critérios meramente formais que caracterizam o sistema tributário". Para calcular o imposto deduzido e verificar o excedente dos limites puníveis nos termos do art. 4. do decreto legislativo $\mathrm{n}^{\circ} 74$ de 2000, componentes de renda negativos também devem ser considerados, desde que sejam legitimamente dedutíveis. Para esse fim, segundo o tribunal, o juiz criminal é o único responsável por determinar o valor do imposto evadido, que deve ser entendido como todo o imposto devido, por meio de uma verificação que também pode contrastar com o que pode ter sido realizado pelo juiz tributário.

95 Destaca NAPOLEONI, V. I fondamenti del nuovo diritto penale tributario. Milano: Ipsoa, 2000. p. 116, 117 e 144, que os limites de punição devem ser qualificados como elementos essenciais do crime que, como o princípio constitucional da culpa, devem ser investidos de conduta dolosa.

96 O que se distancia das regras que os serviços fiscais devem seguir e da instrumentação que eles devem adotar para quantificar e recuperar o imposto não declarado pelo contribuinte sob investigação. Pense, em particular, nas regras penais que afirmam a irrelevância, para fins de cáculo do imposto evadido, do imposto teórico consequente à diminuição do ajuste de perdas no exercício [art. 1, alínea $f$, do d.lgs. n. 74 de 2000] e, sob o perfil da declaração infiel, a negação de relevância, para os fins acima mencionados, às classificações errôneas ou avaliações de elementos ativos ou passivos objetivamente existentes, em conformidade com os critérios para determinar o exercício da competência, de herança ou dedutibilidade de alementos passivos reais, nos termos do art. 4, § 1-bis, de d. Lgs. $\mathrm{n}^{\mathrm{o}} 74$ de 2000, adicionado do art. $4^{\circ}$, $\S 1^{\circ}$, alínea $c$ da d. Lgs. $\mathrm{n}^{\mathrm{o}} 158$ de 2015, cfr. nesse ponto, as considerações claras e amplamente sintonizadas de ROSA, S. Orientamenti e disorientamenti in tema di rapporti tra norme penali e tributarie. Rivista di diritto tributario, v. 26, n. 1, p. 429 e ss., 2016. p. 447, texto e nota 31 .
} 
apuração dos fatos relevantes ${ }^{97}$, respectivamente, do ponto de vista penal ou tributário, bem como da ampla autonomia de decisão reconhecida ao juiz.

Essa divergência potencial no cálculo do imposto evadido não deve ser superada por meio da pregiudiziale tributaria, como também foi proposto na doutrina ${ }^{98}$, segundo a qual a suspensão do julgamento criminal seria necessária enquanto se aguarda a quantificação definitiva do imposto efetivamente devido no processo tributário. Nessa perspectiva, seria necessário unificar a determinação do imposto evadido, e o processo penal não seria a dimensão mais idônea para tal apuração, devendo-se preferir confiar esse cálculo às repartições fiscais e ao juiz tributário ${ }^{99}$.

O instrumento seria o da reintrodução do iure condendo da necessária suspensão do processo penal, ou a legislação inalterada, aplicando o art. 479 do CPP, o qual permite ao juiz criminal suspender a disputa ${ }^{100}$, sob a condição de que a lei não imponha "limitações à prova da controversa posição subjetiva", considerando irrelevante a inadmissibilidade da prova testemunhal no processo tributário, uma vez que “[...] o valor do imposto devido nunca pôde ser provado por meio de testemunhas" ${ }^{" 101}$.

Ao contrário, as "limitações às provas" do art. $7, \S 4^{\circ}$, do Decreto Legislativo $\mathrm{n}^{\circ}$ 546, de 1992, tornam inaplicáveis as disposições do art. 479 do CPP, como não se pode excluir $a$ priori que a prova testemunhal, se fosse admissível no processo tributário, poderia ser usada pelo contribuinte para determinar, mesmo que indiretamente, o imposto efetivamente devido $^{102}$. Mas não pode ser compartilhada a proposta de reintrodução da pregiudiziale tributaria de iure condendo, com uma necessária suspensão do processo penal, a qual resultaria em um retorno anacrônico ao passado e comportaria uma dilatação excessiva e irracional do tempo necessário para a celebração do processo penal, tornando ineficaz e intempestiva a repressão dos crimes em matéria tributária ${ }^{103}$.

97 Considere, a título de exemplo, pressupostos que não atendem aos requisitos de gravidade, precisão e concordância, que provavelmente não provam a existência de um fato, em um processo criminal, da mesma maneira que o art. $192, \S 2^{\circ}$, do CPP. Sobre o ponto, v. de volta ao $\S 2^{\circ}$.

98 Cfr. DORIGO, S. Il "doppio binario" nella prospettiva penale: crisi del sistema e spunti per una riforma. Rassegna tributaria, p. 436 e ss., 2017, e, specialmente 455 ss.

99 Ibid., p. 461 e 462.

100 Até que a questão da existência do crime seja decidida por um julgamento final e dependa da solução de uma disputa em "questões civis ou administrativas de particular complexidade", para as quais o julgamento está pendente perante o juiz competente.

101 Assim, ainda, ibid., p. 460.

102 Salienta sintonicamente CORVI, P. I rapporti tra accertamento tributario e accertamento penale. In: GIARDA, A.; PERINI, A.; VARRASO, G. (coords.). La nuova giustizia penale tributaria. Assago (MI): CEDAM, 2016. p. 467, que a operação do art. 479 do CPP encontra um obstáculo no diferente regime probatório no qual a apuração tributária se baseia.

103 Sem considerar que a paralisia da ação penal, decorrente da aplicação da pregiudiziale tributaria reintroduzida, provocaria a esperança de impunidade para os infratores, com o efeito de aumentar a evasão fiscal, 


\section{CONSIDERAÇÕES FINAIS: O ABANDONO DO DOPPIO BINARIO, A AMPLA CIRCULAÇÃO DE MATERIAL PROBATÓRIO E A AUTONOMIA DECISÓRIA DO}

JUIZ

Ao final deste percurso de pesquisa, a reconstrução do modelo de conexão entre o procedimento e o processo penal ${ }^{104}$, de um lado, e o processo tributário por outro lado, com referência ao imposto de renda e ao IVA, prescinde totalmente do denominado doppio binario perfeito $^{105}$, cuja teoria deve ser abandonada ${ }^{106}$ e da (inexistente) necessidade de reintroduzir a pregiudiziale tributaria. A proposta de reconstrução é orientada de acordo com duas diretrizes fundamentais, intimamente ligadas, e que levam em consideração a diversidade de valores subjacentes às regras penais e tributárias, mesmo quando se referem a fatos materiais comuns à seara penal e tributária.

A primeira diretriz é formada pela ampla circulação de patrimônio probatório do processo penal e do processo tributário, com uma transmigração de uma dimensão para outra $^{107}$, embora com o filtro representado pelo método instrutório que caracteriza o processo tributário, convergindo amplamente para um acordo que favorece o componente escrito e documental e, com poucas exceções, sem prova testemunhal típica ${ }^{108}$. Esse modelo de

em vez de combatê-la de maneira eficaz e reduzi-la significativamente.

104 Destaca corretamente LA ROSA, S. Orientamenti e disorientamenti in tema di rapporti tra norme penali e tributarie. Rivista di diritto tributario, v. 26, n. 1, p. 429 e ss., 2016. p. 448, que o ônus da prova repousa sempre na acusação, independentemente da tipologia de irregularidades encontradas no trabalho do contribuinte e "seu objetivo deve ser visto na extenção do preconceito geral causado pelo sonegador às finanças públicas, uma vez que este é precisamente o elemento constitutivo central do caso criminalmente relevante".

105 Consequentemente, o que afirma a esse respeito não pode ser compartilhado por todo Tribunal Cass. pen., 12 giugno 2019, n. 25976, cit., segundo o qual o art. 20 do d.lgs. n. 74 de 2000 esculpe tout court "a autonomia do processo tributário frente ao penal".

106 Sublinha MARELLO, E. Commento sull'art. 1 del d.lgs. n. 546/1992. In: TESAURO, F. (coord.). Codice commentato del processo tributario. Assago (MI): Utet Giuridica, 2016. p. 280 e 285, que, para a imagem do doppio binario, é necessário preferir a de "dois viajantes que percorrem a mesma estrada", onde "a hipótese da via dupla se mostrou impossível de percorrer" e não seria possível corrigir os inúmeros defeitos de interpretação.

107 Não é de todo compartilhável a afirmação de RUSSO, F. L'equilibrio storico sistematico tra processo penale e tributario alla luce dei principi CEDU e pronunce della Corte EDU. Diritto e pratica tributaria internazionale, 2017. p. 151, segundo o qual os processos criminais e fiscais “[...] são completamente autônomos e carecem de qualquer medida destinada a garantir uma tomada de decisão uniforme, exceto alimentar-se através da transmigração do material preliminar". Essa frase, de fato, coloca fenômenos importantes, mas diferentes, no mesmo nível, que devem ser analisados separadamente, a saber, a autonomia entre os dois ritos processuais, o potencial conflito de juízes e a circulação do material preliminar de um complexo para outro. Forças questionáveis, então, e o aceno para a nutrição, onde o autor afirma que os dois processos se alimentam um do outro, como se o julgamento criminal ou fiscal exigisse comida ou alimento.

108 Embora as relações de terceiros sejam admitidas no processo tributário, elas não violam a proibição referida ao art. $7^{\circ}, \S 4^{\circ}$ de d. Lgs. $n^{\circ} 546$ de 1992: cfr. sobre o ponto amplius COMELLI, A. Le dichiarazioni di terzi sono elementi indiziari liberamente valutabili dal giudice tributario. Corriere tributario, v. 36, p. 637 e ss., 2013; Id. Valenza probatoria delle dichiarazioni rese da terzi nel processo tributario. Corriere tributario, v. 37, p. 2957 e ss., 2014; Id. Dichiarazioni di terzi, inammissibilità della prova testimoniale e presunzioni semplici, ai fini del 
conexão é totalmente incompatível seja com uma ausência absoluta de condicionamentos mútuos entre o procedimento e o processo criminal para crimes tributários e a apuração administrativa e o processo tributário, seja com a impossibilidade de transmigração dos resultados probatórios alcançados de um local para o outro ${ }^{109} \mathrm{e}$, de fato favorece uma osmose não unilateral ${ }^{110}$, no lado probatório ${ }^{111}$.

A segunda diretriz, por fim, é representada pela significativa autonomia, na presença dos mesmos fatos fiscalmente relevantes, que caracterizam a decisão, respectivamente, do juízo penal e tributário, sobre a controvérsia que lhe foi submetida ${ }^{112}$. Essa autonomia decisória, no entanto, depende, em grande parte, dos diferentes objetos do processo e está estritamente ligada à pluralidade de jurisdições que caracterizam o ordenamento estabelecido pela Carta Constitucional.

\section{REFERÊNCIAS}

ALFANO, R. Il potere di disapplicazione del giudice nel processo tributario. Rassegna tributaria, p. 830 e ss., 2007.

AMADEO, R. Art. 13-bis del d.lg. n. 158/2015. In: NOCERINO, C.; PUTINATI, S. (coords.). La riforma dei reati tributari. Torino: Giappichelli, 2015.

processo tributario. Corriere tributario, v. 42, p. 434 e ss., 2019. Por último, cfr. COLLI VIGNARELLI, A. La Corte di cassazione si pronuncia ancora in tema di dichiarazioni di terzi. Bollettino tributario d'informazioni, a. 87, n. 13, p. 971 e ss., 2019.

109 Cfr. CARACCIOLI, I. Superato il "doppio binario" tributario-penale? Corriere tributario, p. 1007 e ss., 2014.

$110 \mathrm{Cfr}$., com referência às aquisições de provas no contexto da autuação fiscal e do processo tributário, no que diz respeito ao processo criminal, BELLAGAMBA, G.; CARITI, G. Il sistema delle sanzioni tributarie. Milano: Giuffrè, 2011. p. 286 e 287; IORIO, A.; MECCA, S. Utilizzabilità del pvc e degli altri atti del Fisco nel processo penale. Corriere tributario, p. 3220 e ss., 2016.

111 CORVI, P. I rapporti tra accertamento tributario e accertamento penale. In: GIARDA, A.; PERINI, A.; VARRASO, G. (coords.). La nuova giustizia penale tributaria. Assago (MI): CEDAM, 2016. p. 495, salienta que "[...] a osmose da apuração penal para a a apuração tributária emerge de uma série de índices que configuram o julgamento criminal como um veículo privilegiado para notícias de relevância fiscal e de provas para fins de uma apuração tributária a mais completa e oportuna possível".

112 Uma conclusão diferente não é alcançada, mesmo considerando a orientação expressa pelo Tribunal de cassação no arresto 30 maio 2019, n. 24152, cit., segundo o qual os processos fiscais e criminais têm objetivos distintos, nomeadamente o primeiro "visa essencialmente recuperar o quantum processado", enquanto o segundo “[...] se destina a verificar, além de qualquer razoável dúvida, a atribuição ou não da conduta ilegal do acusado, portanto, sua culpa e sanção". Em virtude desses objetivos distintos, acrescenta o Tribunal, os elementos coletados na área tributária são usados como meras pistas pelo juiz criminal, com uma apreciação independente, da mesma forma que a sua gravidade, precisão e concordância, "juntamente com a parte restante dos ativos probatórios disponíveis", adquiridos durante o curso da audiência, as presunções físcais não são assumidas com o efeito de segurança jurídica. Para serem consideradas provas, deverão encontrar "[...] respostas objetivas ou elementos distintos ou em outras suposições, desde que sejam sérias, precisas e concordantes", seguindo o "[...] procedimento indutivo que permite inferir com certeza os dados desconhecidos do conhecido". 
AMATUCCI, F. Doppio binario e "connessione sufficiente" tra procedimento tributario e penale. Rivista trimestrale di diritto tributario, a. 2017, n. 2, p. 271 e ss., 2017.

AMATUCCI, F. Le sanzioni amministrative tra principio di proporzionalità e ne bis in idem. In: COMELLI, A. (coord.). Nuove problematiche e prospettive di evoluzione del sistema dell'iva. Atti del VII convegno annuale 23 marzo 2017 (23 mar. 2017). Canterano (RM): Aracne, 2018. p. 57 e ss.

BALENA, G. La nuova pseudo-riforma della giustizia civile (un primo commento della 1. 18 giugno 2009, n. 69). Giusto processo civile, p. 756 e ss., 2009.

BECCALLI, C. Dal patteggiamento penale solo significativi elementi di prova per il giudice tributario. Fisco, p. 577 e ss., 2015.

BELLAGAMBA, G.; CARITI, G. Il sistema delle sanzioni tributarie. Milano: Giuffrè, 2011.

BIANCHI, L. Le sanzioni tributarie in materia di accise. In: CADOPPI A. et al. (coords.). Diritto penale dell'economia. t. I. 2. ed. Milano: Utet Giuridica, 2019. (no prelo)

CABRAL, A. Per un nuovo concetto di giurisdizione. In: BRIGUGLIO, A. et al (coords.). Scritti in onore di N. Picardi. T. I. Pisa: Pacini, 2016.

CARACCIOLI, I. Salvato a metà dai giudice europei il doppio binario tributario-penale. Corriere tributario, p. 1029 e ss., 2013.

CARACCIOLI, I. Superato il "doppio binario" tributario-penale? Corriere tributario, p. 1007 e ss., 2014.

CARINCI, A. La nuova disciplina dei costi da reato: dal superamento del doppio binario alla dipendenza rovesciata (con diversi dubbi e numerose incongruenze). Rassegna tributaria, $\mathrm{p}$. 1459 e ss, 2012.

CAVALLONE, B. Riflessione sulla cultura della prova. Rivista italiana di diritto e procedura penale, p. 947 e ss., 2008.

CHIZZINI, A. I rapporti tra codice di procedura civile e processo tributario. In: TESAURO, F. (coord.). Il processo tributario. Torino: Utet, 1998. (Giurisprudenza sistematica del diritto tributario)

CHIZZINI, A. La domanda giudiziale e il suo contenuto. Milano: Giuffrè, 2018.

CHIZZINI, A. La tutela giurisdizionale dei diritti. Milano: Giuffrè, 2018.

CICALA, M. La giurisdizione tributaria. Fisco, p. 2047 e ss., 2005.

COLLI VIGNARELLI, A. La Corte di cassazione si pronuncia ancora in tema di dichiarazioni di terzi. Bollettino tributario d'informazioni, a. 87, n. 13, p. 971 e ss., 2019. 
COMELLI, A. Commento sull'art. 7 del D.Lgs. n. 546/1992. In: CONSOLO, C.; GLENDI, C. (coords.). Commentario breve alle leggi del processo tributario. Padova: Cedam, 2017. p. 96 e ss.

COMELLI, A. Dichiarazioni di terzi, inammissibilità della prova testimoniale e presunzioni semplici, ai fini del processo tributario. Corriere tributario, v. 42, p. 434 e ss., 2019.

COMELLI, A. L'armonizzazione (e il ravvicinamento) fiscale tra lo "spazio unico europeo dell'iva", la direttiva del Consiglio "contro le pratiche di elusione fiscale" e l'abuso del diritto. Diritto e pratica tributaria, v. 89, n. 4, p. 1397-1436, 2018.

COMELLI, A. Le dichiarazioni di terzi sono elementi indiziari liberamente valutabili dal giudice tributario. Corriere tributario, v. 36, p. 637 e ss., 2013.

COMELLI, A. Valenza probatoria delle dichiarazioni rese da terzi nel processo tributario. Corriere tributario, v. 37, p. 2957 e ss., 2014.

COMOGLIO, L. P. Prove penali, "giusto processo" e poteri di acquisizione del giudice tributario. Diritto e pratica tributaria, v. 71, n. 4, p. 943-971, 2000.

CONSOLO, C. Translatio, regolamento, ragionevole durata e disciplina (anch'essa ragionevole) delle "liti” sulla giurisdizione. Corriere giuridico, p. 351 e ss., 2011.

CONSOLO, C.; STELLA, M. Commento sull'art. 39 del d.lgs. n. 546/1992. In: GLENDI, C.; CONSOLO, C.; CONTRINO, A. (coords.). Abuso del diritto e novità sul processo tributario. Milano: Ipsoa, 2016.

CORSO, P. Obbligo per il P.M. di segnalare all'Agenzia delle entrate proventi illeciti suscettibili di imposizione fiscale. Corriere tributario, p. 325 e ss., 2016.

CORSO, P. Raddoppio dei termini di accertamento tra Legge delega e Suprema Corte. Corriere tributario, p. 2235 e ss., 2015.

CORVI, P. I rapporti tra accertamento tributario e accertamento penale. In: GIARDA, A.; PERINI, A.; VARRASO, G. (coords.). La nuova giustizia penale tributaria. Assago (MI): CEDAM, 2016.

DEBOISSY, F. Retour sur un principe controversé: l'indépendance des procédure pénale et fiscale. Revue de droit fiscal, a. 2014, n. 51-52, 18 dez. 2014.

DONELLI, F. Le fattispecie penali in materia di accise. In: CADOPPI A. et al. (coords.). Diritto penale dell'economia. t. 1. 2. ed. Milano: Utet Giuridica, 2019. (no prelo)

DORIGO, S. Il "doppio binario" nella prospettiva penale: crisi del sistema e spunti per una riforma. Rassegna tributaria, p. 436 e ss., 2017.

FABIANI, E. Unità della giurisdizione, effettività della tutela giurisdizionale e possibili modelli di (istruttoria del) processo: riflessioni sparse. In: FABIANI, E.; TARTAGLIA 
POLCINI, A. (coords.). Sull'unità della giurisdizione in ricordo di F. Cipriani. Napoli: Edizioni Scientifiche Italiane, 2011.

FABIANI, E.; TARTAGLIA POLCINI, A. (coords.). Sull'unità della giurisdizione in ricordo di F. Cipriani. Napoli: Edizioni Scientifiche Italiane, 2011.

FALSITTA, G. Manuale di diritto tributario. Parte generale. Padova: CEDAM, 2017.

FANNI, M. Commento sull'art. 7 del d.lgs. n. 546/1992. In: TESAURO, F. (coord.). Codice commentato del processo tributario. Assago (MI): Utet Giuridica, 2016.

FICHERA, F. L'oggetto della giurisdizione tributaria e la nozione di tributo. Rassegna tributaria, p. 1059 e ss., 2007.

FRANSONI, G. La disapplicazione dei regolamenti e degli atti generali. In: TESAURO, F. (coord.). Il processo tributario. Torino: Utet, 1998. (Giurisprudenza sistematica del diritto tributario)

FRANSONI, G. Osservazioni controcorrente sul doppio termine dell'accertamento. Rassegna tributaria, p. 311 e ss., 2012.

FRANSONI, G. Rilevanza processuale penale del "fatto fiscale" e rilevanza processuale fiscale del "fatto penale". Rivista di diritto tributario, v. 26, n. 1, p. 1 e ss, 2016.

GAFFURI, A. Commento sull'art. 39 del d. Lgs. n. 546/1992. In: TESAURO, F. (coord.). Codice commentato del processo tributario. Assago (MI): Utet Giuridica, 2016.

GIOVANNINI, A. Giustizia civile e giustizia tributaria: gli archetipi e la riforma. Rassegna tributaria, p. 14 e ss., 2014.

GIOVANNINI, A. La Corte EDU ribadisce il divieto di doppia sanzione e la Cassazione rinvia alla Consulta. Corriere tributario, p. 905 e ss., 2015.

GLENDI, C. "Translatio iudicii" tra diverse giurisdizioni: problemi pratici e prospettive "in apicibus" (con particolare riguardo alla giurisdizione tributaria). GT-Rivista di giurisprudenza tributaria, p. 557 e ss., 2007.

GLENDI, C. La circolarità dell'azione tra le diverse giurisdizioni dell'ordinamento nazionale. Corriere tributario, p. 2655 e ss., 2009.

GLENDI, C. La circolarità dell'azione tra le diverse giurisdizioni dell'ordinamento nazionale. Diritto e pratica tributaria, v. 81, n. 1, p. 121-143, 2010.

GLENDI, C. La giurisdizione nel quadro evolutivo di nuovi assetti ordinamentali. Giusto processo civile, p. 337 e ss., 2009.

GLENDI, C. La giurisdizione tributaria nel prisma dell'ordinamento. Diritto e pratica tributaria, v. 81, n. 2, p. 315 e ss., 2010. 
GLENDI, C. Nuova disciplina del processo civile di cognizione e processo tributario. Corriere tributario, p. 2954 e ss., 2010.

GLENDI, C. Nuove disposizioni generali del codice di procedura civile e processo tributario. Corriere tributario, p. 2561 e ss., 2010.

GLENDI, C. Oggetto del processo e "translatio iurisdictionis". Diritto e pratica tributaria, v. 84, n. 1, p. 69 e ss, 2013.

GLENDI, C. Rapporti tra nuova disciplina del processo tributario e codice di procedura civile. Diritto e pratica tributaria, v. 71, n. 6, p. 1700-1711, 2000.

GLENDI, C. Rapporti tra regole generali del processo civile e disciplina speciale del processo tributario. Corriere tributario, p. 3067 e ss., 2007.

GLENDI, C. Translatio iudicii e compiti del regolamento di giurisdizione, con esame anche dell'incidenza scoordinata del nuovo "codice della giustizia amministrativa". Corriere giuridico, p. 758 e ss., 2010.

GRANELLI, A. E. Presunzioni tributarie e processo penale. Diritto e pratica tributaria, a. 1985, n. 1, p. 34 e ss., 1985.

GUIDI, D. I rapporti tra processo penale e processo tributario ad oltre dieci anni di distanza dal D.Lgs. n. 74 del 2000. Dir. pen. e processo, p. 1384 e ss., 2012.

IANNACCONE, G. Diritto tributario e processo penale. In: GLENDI, C. et al (coords.). Per un nuovo ordinamento tributario. Atti del convegno di Genova del 14-15 out. 2016, in occasione dei Novant'anni di Diritto e pratica tributaria. t. 2. Milano: CEDAM, 2019. p. $1445-1457$.

IORIO, A.; MECCA, S. Utilizzabilità del pvc e degli altri atti del Fisco nel processo penale. Corriere tributario, p. 3220 e ss., 2016.

IORIO, A.; MECCA, S. Utilizzo delle intercettazioni nei procedimenti per reati tributari. Fisco, p. 2472 e ss., 2014.

LA ROSA, S. Orientamenti e disorientamenti in tema di rapporti tra norme penali e tributarie. Rivista di diritto tributario, v. 26, n. 1, p. 429 e ss., 2016.

LA ROSA, S. Principi di diritto tributario. Torino: Giappichelli, 2016.

LOCONTE, S. Commento sull'art. 39 del d.lgs. n. 546/1992. In: CONSOLO, C.; GLENDI, C. (coords.). Commentario breve alle leggi del processo tributario. Padova: Cedam, 2017. p. 555 e ss.

MANCINI, A. Diritto penale tributario. Roma: Laurus Robuffo, 2019.

MANDRIOLI, C. Giurisdizione (in generale). In: DIGESTO delle discipline privatistiche. Sezione civile. v. IX. 2. reimpr. Assago (MI): Utet Giuridica, 2013. 
MANONI, E. Le sentenze penali di patteggiamento costituiscono elementi probatori da valutare nel giudizio tributario. Fisco, p. 3545 e ss., 2018.

MANONI, E. Riflessioni sul rapporto tra sistema penale e sistema tributario. Rassegna tributaria, p. 1034 e ss., 2014.

MARCHESELLI, A. La circolazione dei materiali istruttori dal procedimento penale a quello tributario. Rassegna tributaria, p. 83 e ss., 2009.

MARELLO, E. Commento sull'art. 1 del d.lgs. n. 546/1992. In: TESAURO, F. (coord.). Codice commentato del processo tributario. Assago (MI): Utet Giuridica, 2016.

MARELLO, E. Evanescenza del principio di specialità e dissoluzione del doppio binario: le ragioni per una riforma del sistema punitivo penale tributario. Rivista di diritto tributario, $\mathrm{v}$. 23, n. 3, p. 270 e ss., 2013.

MARELLO, E. Il raddoppio dei termini per l'accertamento al vaglio della Corte Costituzionale. Rassegna tributaria, p. 1296 e ss., 2011.

MARELLO, E. Raddoppio dei termini per l'accertamento e crisi del "doppio binario". Rivista di diritto tributario, v. 20, n. 3, p. 85 e ss., 2010.

MASTROGIACOMO, E. Commento sull' art. 20 del d.lgs. n. 74/2000. In: MOSCHETTI, F. (coord.), Commentario breve alle leggi tributarie. t. II. Padova: CEDAM, 2011.

MELIS, G. Sulla nuova disciplina degli effetti penali dell'estinzione del debito tributario e su taluni possibili interventi migliorativi. In: In: GLENDI, C. et al (coords.). Per un nuovo ordinamento tributario. Atti del convegno di Genova del 14-15 out. 2016, in occasione dei Novant'anni di Diritto e pratica tributaria. t. 2. Milano: CEDAM, 2019. p. 1481-1524.

MICCINESI, M. Commento sull'art. 1. In: BAGLIONE, T.; MENCHINI, S.; MICCINESI, M. Il nuovo processo tributario. Commentario. Milano: Giuffrè, 1997. p. 5 e ss.

MITA, E. de. Uno sguardo d'insieme. L'opinione. In: GIARDA, A.; PERINI, A.; VARRASO, G. (coords.). La nuova giustizia penale tributaria. Assago (MI): CEDAM, 2016.

MONFREDA, N.; STELLA, F. Eficacia della sentenza penale nel processo tributario. Fisco, p. 4494 e ss., 2013.

MONTELEONE, G. Difetto di giurisdizione e prosecuzione del processo: una confusa pagina di anomalie processuali, Rivista di diritto processuale, v. 65, n. 2, p. 271 e ss., 2010.

NANNUCCI, U. I rapporti tra il procedimento penale e il processo tributario. In: NANNUCCI, U.; D’AVIRRO, A. (coords.). La riforma del diritto penale tributario (D.Lgs. 10 mar. 2000, n. 74). Padova: CEDAM, 2000. 
NAPOLEONI, V. I fondamenti del nuovo diritto penale tributario. Milano: Ipsoa, 2000.

NICOSIA, G. Giurisdizione nel diritto romano, In: DIGESTO delle discipline privatistiche. Sezione civile. v. IX. 2. reimpr. Assago (MI): Utet Giuridica, 2013. p. 120 e ss.

NOBILI, M. Il principio del libero convincimento del giudice. Milano: Giuffrè, 1974.

PERINI, A. La riforma dei reati tributari. Dir. pen. e proc., p. 31 e ss., 2016.

PIETRO, A. di. Diritto penale tributario: profili comparati. Rassegna tributaria, p. 333 e ss., 2015.

PISANI, M. Giurisdizione penale. In: ENCICLOPEDIA del diritto. v. XIX. Milano: Giuffrè, 1970. p. 381 e ss.

PISTOLESI, F. Crisi e prospettive del principio del "doppio binario" nei rapporti fra processo e procedimento tributario e giudizio penale. Rivista di diritto tributario, v. 24, n. 1, p. 38 e ss., 2014.

PISTOLESI, F. Il principio del doppio binario e l'utilizzabilità delle prove penali nel processo tributario. Fisco e reato. Atti delle "Giornate di Studi", Brescia (24 abr. 2015), Catania (19 jun. 2015) e Bologna (16 out. 2015). Pisa: Pacini, 2016.

POLI, R. Gli standard di prova in Italia. Giurisprudenza italiana, p. 2517 e ss., 2018.

RANDAZZO, F. I confini della giurisdizione tributaria sul versante della riscossione e dell'esecuzione forzata tributaria. In: BASILAVECCHIA, M.; TABET, G. (coords.). La giurisdizione tributaria nell'ordinamento giurisdizionale. Atti del convegno di Teramo, $22 \mathrm{e}$ 23 nov. 2007. Bologna: Gedit, 2009. p. 49 e ss.

RANDAZZO, F. Manuale di diritto tributario. Torino: Giappichelli, 2018.

RANDAZZO, F. Per il raddoppio dei termini dell'accertamento tributario necessaria la denuncia di reato. Corriere tributario, p. 1533 e ss., 2015.

RICCI, E. F. Declinatoria di giurisdizione e (così detta) translatio iudicii. Rivista di diritto processuale, v. 63, n. 3, p. 693 e ss., 2008.

RUSSO, F. L'equilibrio storico sistematico tra processo penale e tributario alla luce dei principi CEDU e pronunce della Corte EDU. Diritto e pratica tributaria internazionale, 2017.

RUSSO, P. Il principio di specialità ed il divieto del ne bis in idem alla luce del diritto comunitario. Rivista di diritto tributario, v. 26, n. 1, p. 23 e ss., 2016.

RUSSO, P. Il riparto della giurisdizione fra giudice tributario e giudice amministrativo e contabile. In: BASILAVECCHIA, M.; TABET, G. (coords.). La giurisdizione tributaria nell'ordinamento giurisdizionale. Atti del convegno di Teramo, 22 e 23 nov. 2007. Bologna: Gedit, 2009. p. 91 e ss. 
SATTA, S. Giurisdizione (nozioni generali). In: ENCICLOPEDIA del diritto. v. XIX. Milano: Giuffrè, 1970.

SCHIAVOLIN, R. Alcune considerazioni sul contrasto tra CEDU e disciplina italiana dei rapporti tra procedure sanzionatorie amministrative e penali. Rivista di diritto tributario, $\mathrm{v}$. 27, n. 1, p. 385 e ss., 2017.

SCHIAVOLIN, R. L’utilizzazione fiscale delle risultanze penali. Milano: Giuffrè, 1994.

SIENA, M. di. Doppio binario tra procedimenti tributario e penale: una metafora ferroviaria in crisi? Fisco, p. 4259 e ss., 2014.

SIENA, M. di. Rapporti tra processo tributario e procedimento penale. In: LIBRO dell'anno di diritto. Roma: Ist. Enciclopedia Italiana, 2013. p. 447 e ss.

STAGNO, M. Art. 20 d.lg. n. 158/2015. In: NOCERINO, C.; PUTINATI, S. (coords.). La riforma dei reati tributari. Torino: Giappichelli, 2015.

STEVANATO, D. Fondamenti di diritto tributario. Firenze: Le Monnier Università, 2019.

STEVANATO, D. Il raddoppio dei termini per l'accertamento nella sentenza della Corte costituzionale n. 247/2011: una pronuncia dagli effetti (involontariamente) criminogeni? Dialoghi tributari, p. 474 e ss., 2011.

STEVANATO, D. Procedimento tributario e nuovi reati: l'accertamento divenuto definitivo vincola il giudice penale? In: LUPI, R. (coord.). Fiscalità d'impresa e reati tributari. Milano: II Sole 24 Ore, 2000.

TABET, G. Collegamento tra fattispecie tributaria e fattispecie penale: riflessioni di diritto processuale. Rassegna tributaria, p. 303 e ss., 2015.

TABET, G. La lunga metamorfosi della giurisdizione tributaria. GT-Rivista di giurisprudenza tributaria, 2014, p. 465 e ss.

TABET, G. Una giurisdizione speciale alla ricerca della propria identità. Rivista di diritto tributario, v. 19, n. 1, p. 32 e ss., 2009.

TESAURO, F. Ammissibilità nel processo tributario delle prove acquisite in sede penale. Rassegna tributaria, p. 323 e ss., 2015.

TESAURO, F. Giurisdizione tributaria e diritto comunitario. GT-Rivista di giurisprudenza tributaria, p. 465 e ss., 2007.

TOPPAN, A.; TOSI, L. Lineamenti di diritto penale dell'impresa. Milano: CEDAM, 2017.

TRAVERSI, A. La crisi del "doppio binario" tra contenzioso fiscale e processo penale. Fisco, p. 3800 e ss., 2011. 
UBERTIS, G. Prova: II) teoria generale del processo penale. In: ENCICLOPEDIA giuridica Treccani. v. XXVIII. Roma: Ist. Enciclopedia Italiana, 2008.

VIGONI, D. L'effetto vincolante del giudicato penale in altri settori dell'ordinamento: le coordinate normative. Rivista di diritto processuale, v. 72, n. 4-5, p. 912 e ss., 2017.

VILLATA, R. La giurisdizione amministrativa e il suo processo sopravviveranno ai "cavalieri dell'apocalisse'? Rivista di diritto processuale, v. 72, n. 1, p. 106 e ss., 2017.

\section{DADOS DA PUBLICAÇÃO}

Categoria: artigo de autor convidado.

Recebido em: 22/03/2020.

Aceito em: 01/07/2020. 
